

\title{
OUTLINES OF AGRICULTURE
}

\author{
IN \\ J APAN.
}

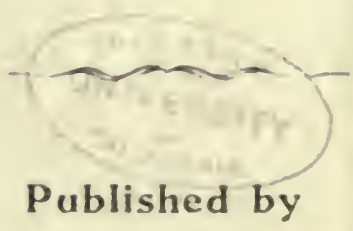

Agricultural Bureau,

Department of Agriculture and Commerce.

TOKYO.

1914. 


$$
\begin{aligned}
& 547 ! \\
& 5342 \\
& 1914
\end{aligned}
$$

$$
a j
$$

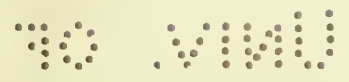

¿

, is 


\section{CONTENTS.}

\section{INTRODUCTION.}

CHAPTER I. Condition of Agriculture

I. P'osition of Agriculture

2. Farmers and Their Condition

Number of Earming Households. - The Movement of Agricultural P'opulation.-Classes of Farmers

3. : Agricultúral Land and Its Condition

Area of Agricultural L_and.-Utilization of Agricultural Land.-Adjustment of Arable Land.-Reclamation of Land

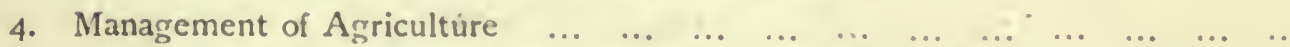

Outline of Management.-Utilization of Animal Labour.-Amount of Consumption of Fertilizers. - Subsidiary Occupations of Farmers.-Cooperative Management

CHAPTER II. Agricultural Products...

I. Total Amount of Agricultural Products ...

\section{8}




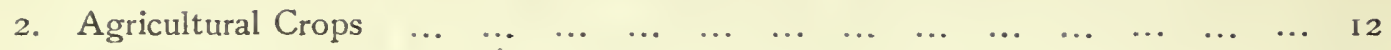

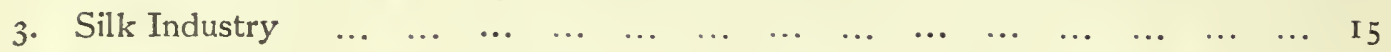

4. Animal Industry and Poultry $\ldots \begin{array}{lllllllllllll} & \ldots & \ldots & \ldots & \ldots & \ldots & \ldots & \ldots & \ldots & \ldots & \ldots & \text { I7 }\end{array}$

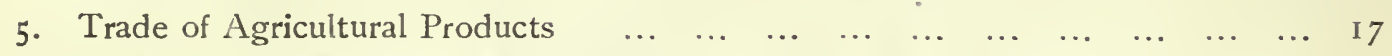

$\begin{array}{lllllllllllll}\text { CHAPTER III. Agricultural Administration } & \ldots & \ldots & \ldots & \ldots & \ldots & \ldots & \ldots & \ldots & \ldots & \text { I9 }\end{array}$

I. Organs of Agricultural Administration $\ldots \begin{array}{llllllllll}\ldots & \ldots & \ldots & \ldots & \ldots & \ldots & \ldots & \ldots & \ldots & \text { I9 }\end{array}$

$\therefore \quad$ Central Organs of:Agricultural Administration.-Local Organs of Agricultural Administration

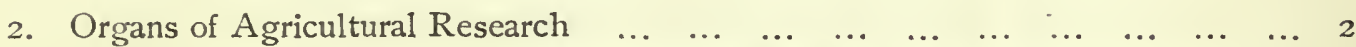

Imperial Agricultural Experimental Station.--Local Agricultural Experimental Stations. - Sericultural Institute.-Government Stock Farm, Cattle Breeding Station, Stallion Stud and Stallion Depot.-Miscellaneous

3. Educational Organs of Agriculture $\ldots \begin{array}{llllllllllll}\ldots & \ldots & \ldots & \ldots & \ldots & \ldots & \ldots & \ldots & \ldots & \ldots & 22\end{array}$

Higher Organs.-Common Organs.-Miscellaneous

4. Provisions Relating to Agricultural Encouragement $\quad \ldots \quad \ldots \quad \ldots \quad \ldots \quad \ldots \quad \ldots$

Agricultural Societies.-Co-operative Societies.-Different' Kinds of Guilds.-Arable Land Adjustment.-Inspection of Raw Silk.-Distribution of Silkworm Eggs for Reproduction.-Crossing of Livestock and distribution of Hatching-eggs.-Inspection of Rice.-Official Control of Com- 
mercial Fertilizers.-Agricultural Monetary Organs.-Exhibitions, Shows and? Fairs. - Miscellaneous

5. Provisions Relating to the Prevention of Calamities $\begin{array}{lllllll}\ldots & \ldots & \ldots & \ldots & \ldots & \ldots & 28\end{array}$

Prevention of Flond.-Prevention and Extermination of Plant disease and Injurious Insects.-P'revention of Silkworm Diseases.-Prevention of Animal Diseases.-Inspection of Plants

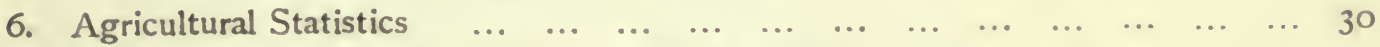

CHAPTER IV. Outlines of Agriculture in the Culonies...

I. Agriculture in Formosa

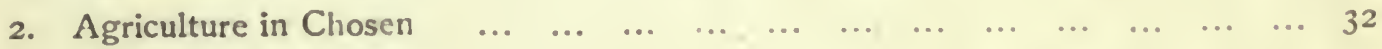

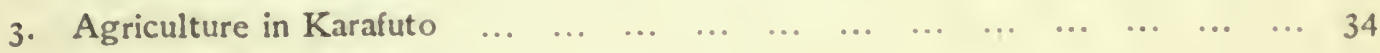




\section{ILLUSTRATIONS}

$=x$

I. The Hall of the Imperial Department of Agriculture and Commerce.

2. The Agricultural College of the Tokyo Imperial University.

3. The Agricultural College of the Tohoku Imperial University, Sapporo, Hokkaido.

4. The Imperial Agricultural Experimental Station.

5. The Horticultural Experimental Farm, Okitsu.

6. The Tea Garden and Tea Picking.

7. Refined Tea Manufactories.

8. The Orchard and Prevention of Injurious Insects.

9. Rice Cultivation of the Adjusted Paddy Fields.

10. Water Course.

11. Engine of drainage.

12. The Bush Plantation of Mulberry trees.

I3. Interior of Filature.

I4. Filature at Okaya, Nagano-Ken.

15 Silk Conditioning House. 
16. The Sericultural Institute.

I7. The Government Stock Farm, Nanatsukahara.

18. The Animal Quarantine Station (Yokohama).

I9. Jinseki Bull.

20. Shibuya Live-stock Breeding Farm, and Long Tail Fowl. 


\section{Digitized by the Internet Archive in 2008 with funding from Microsoft Corporation}

http://www.archive.org/details/outlinesofagricu00japarich 


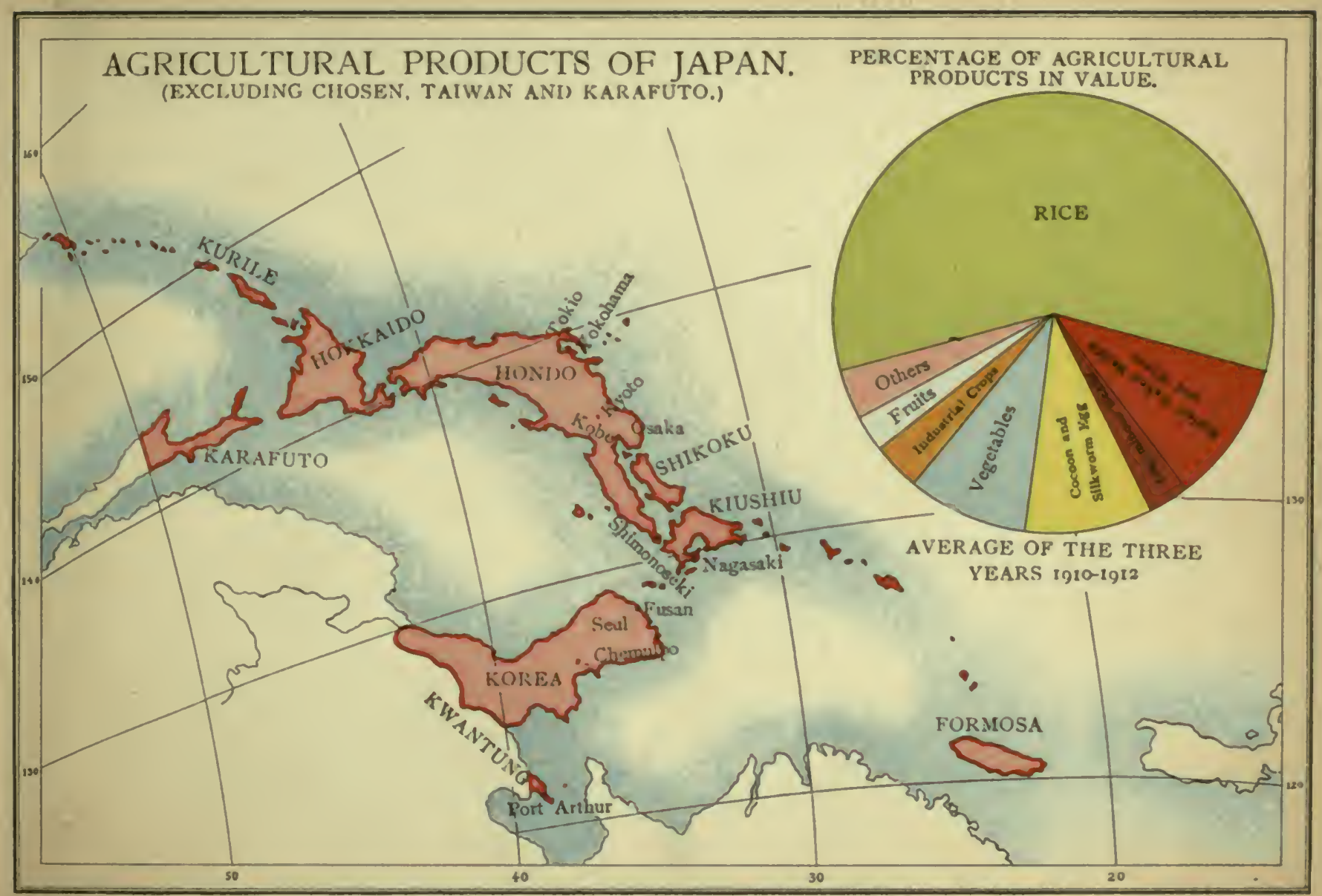




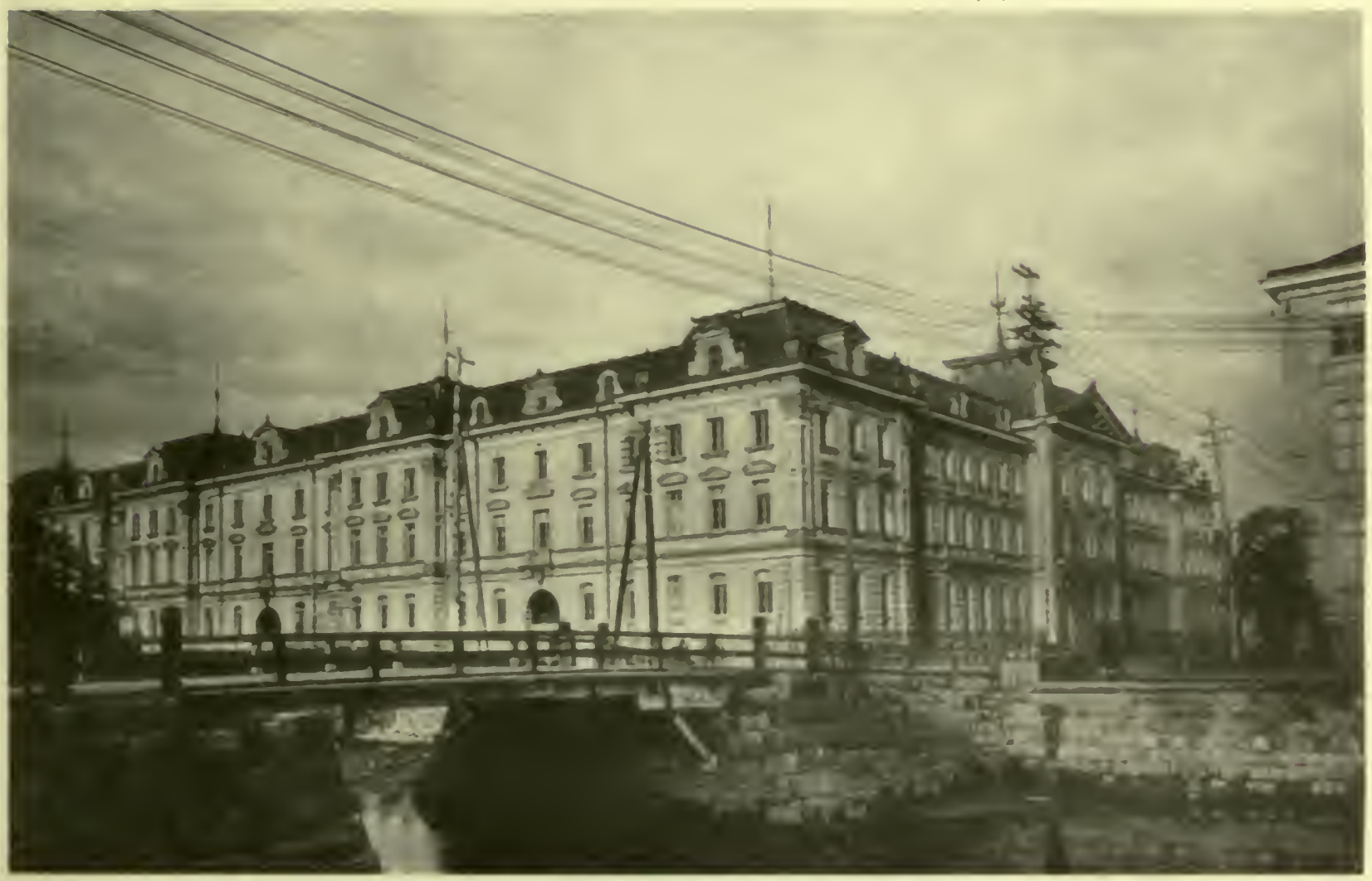

The Hall of the Imperial Department of Agrieulture and Commerce. 


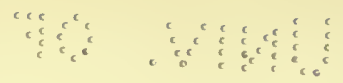

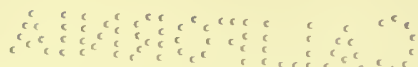



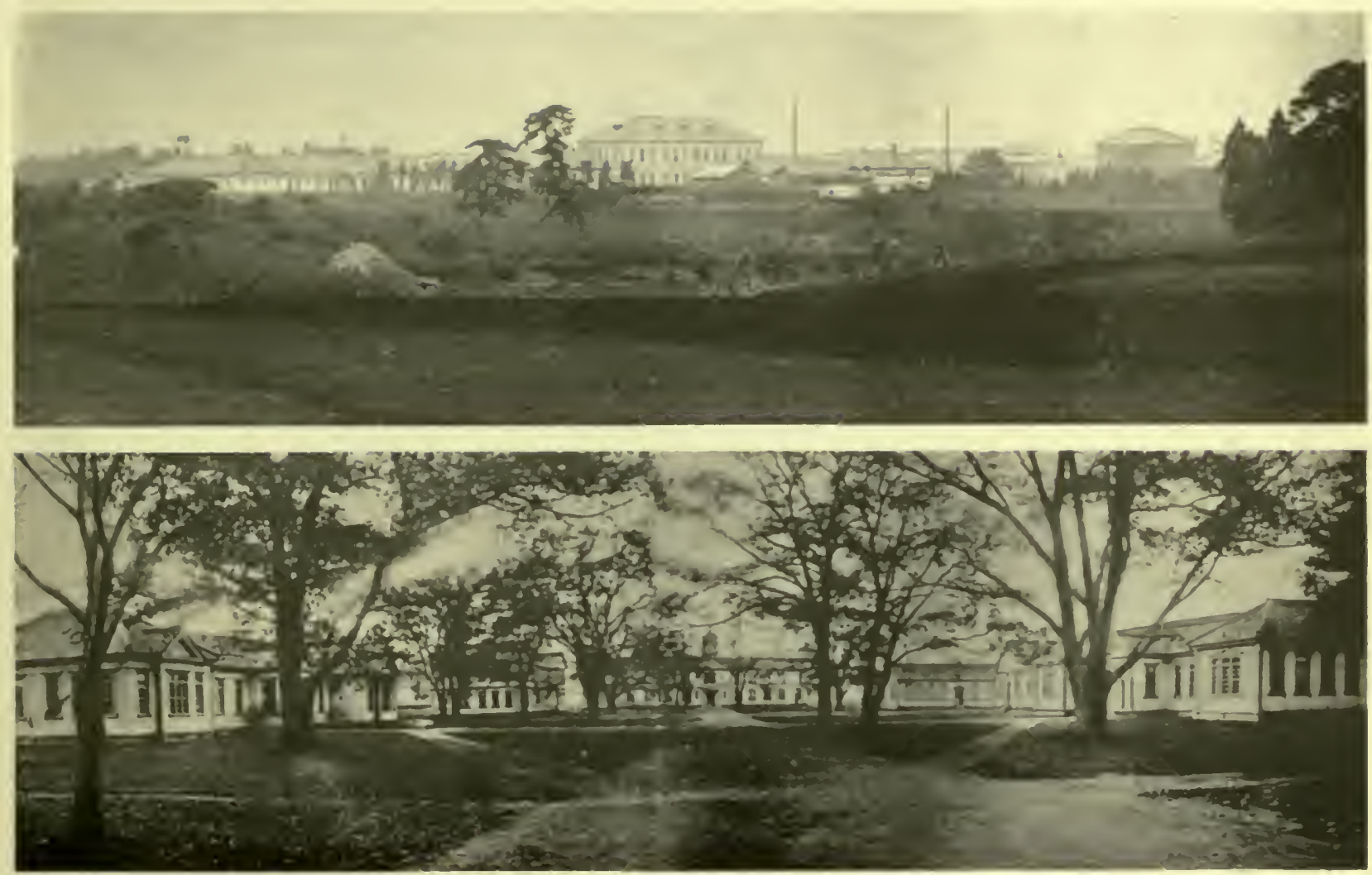

The Agricultural College of the Tokyo Imperial University.

The Agricultural College of the Tohokil Imperial University, Sapporo, Hokkaido. 


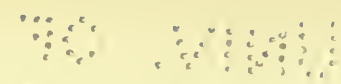

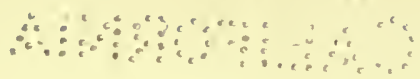




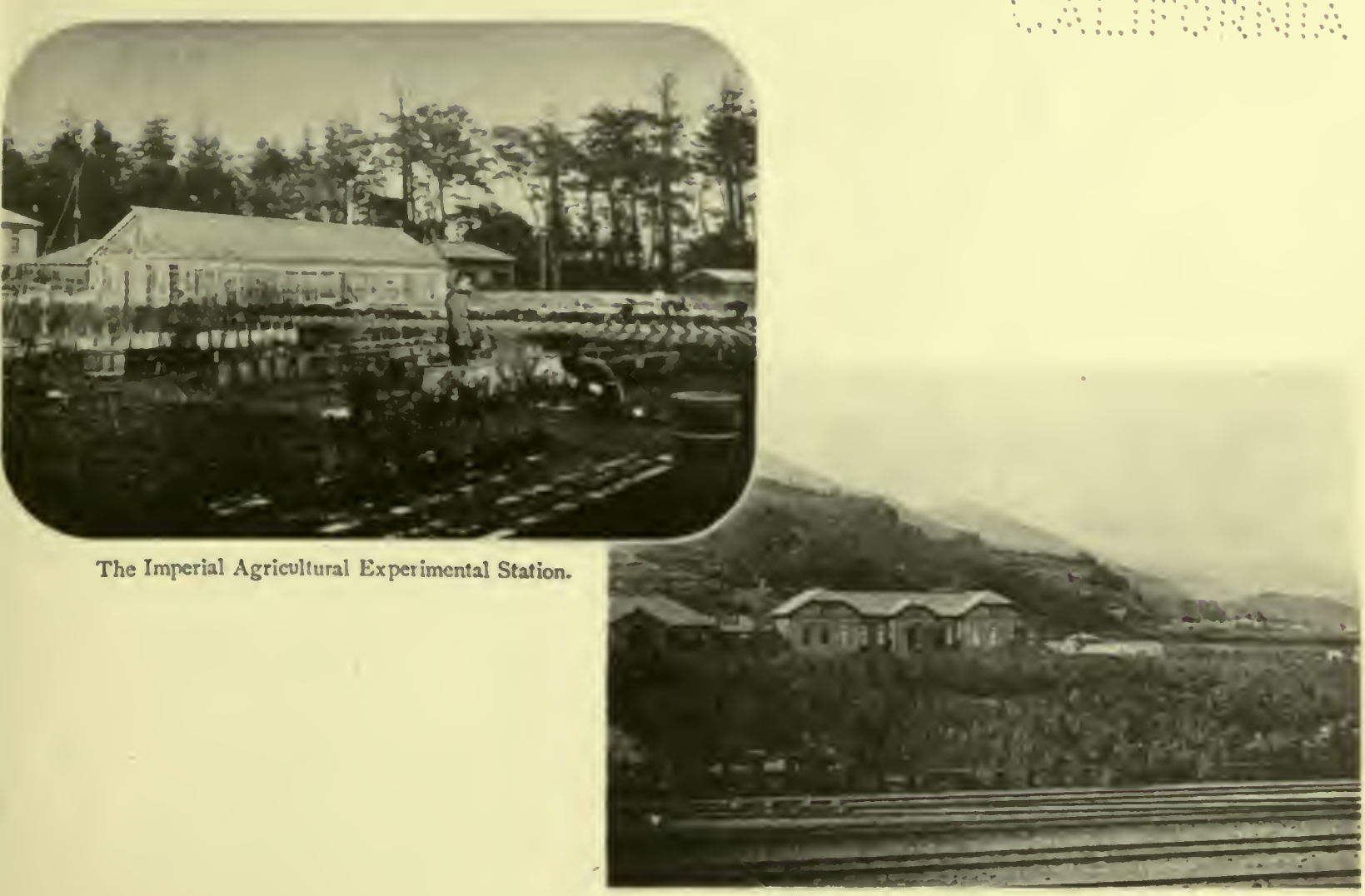

The Horticultural Experimental Farm, Okitsu. 


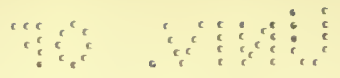

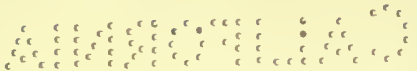

$\Leftrightarrow$ 

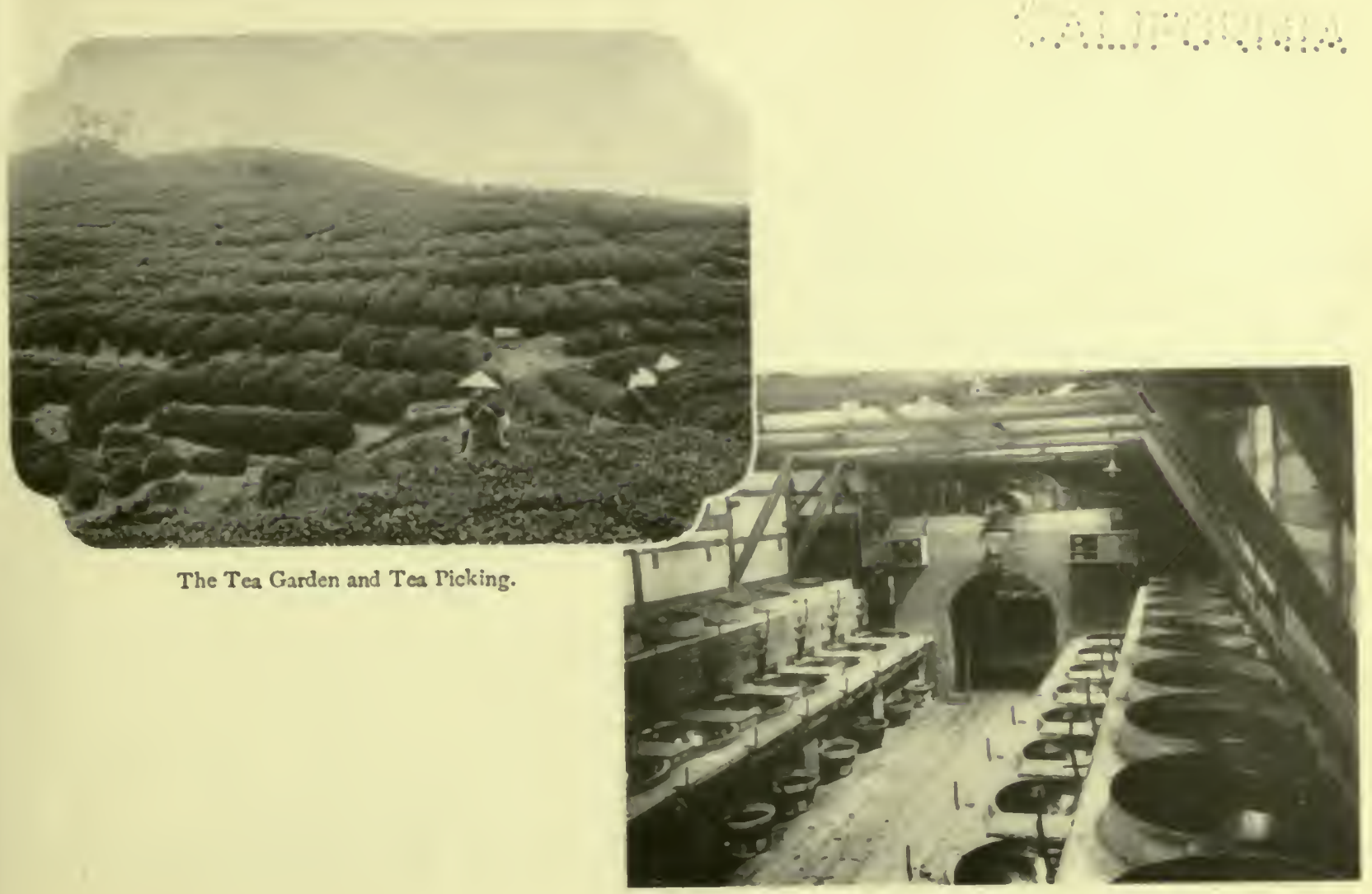

Refinod Tea Manufactories. 


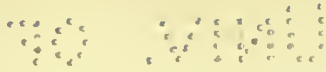

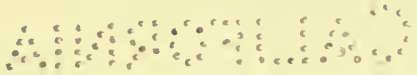




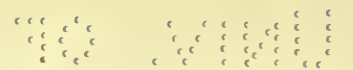

$\therefore$ 


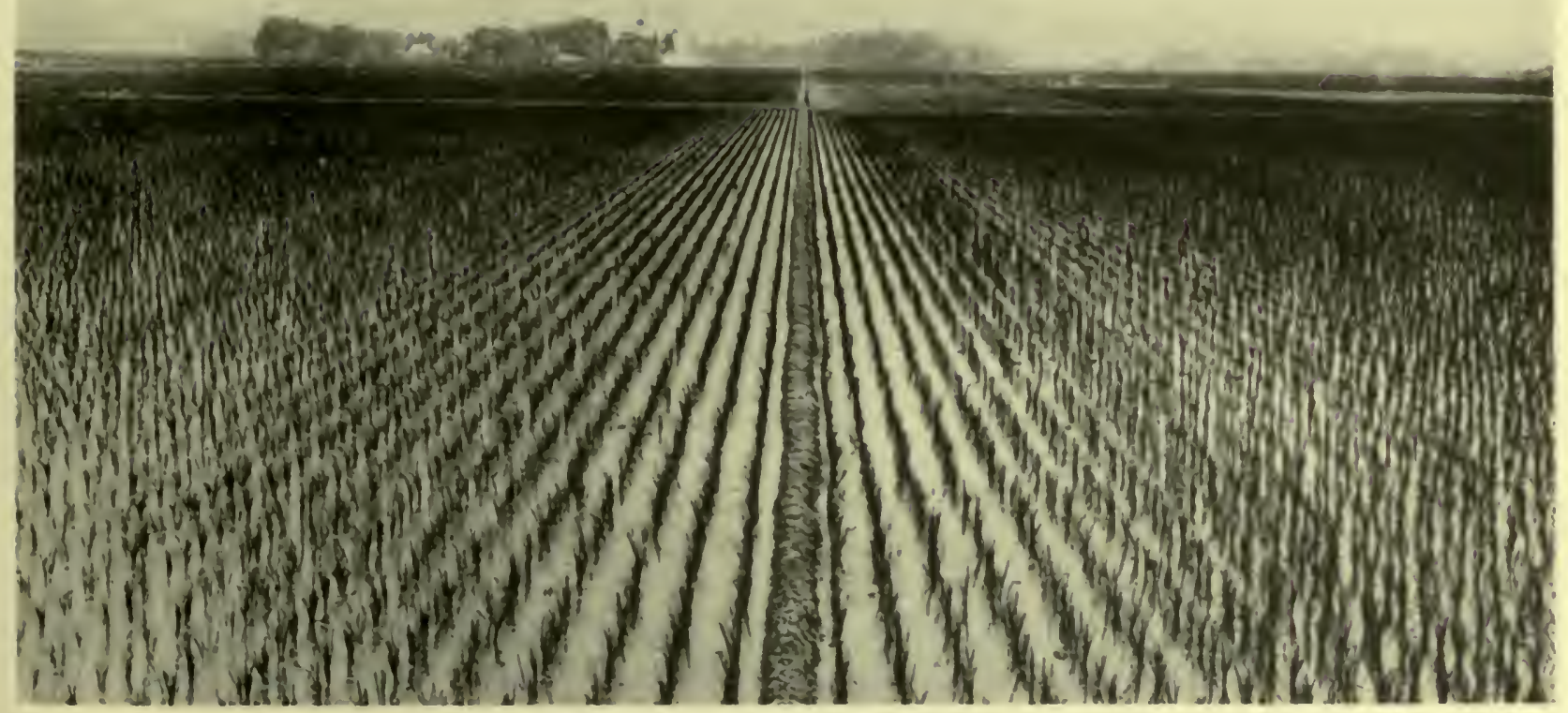

Rice Cultivation of the Adjusted Paddy Fields. 


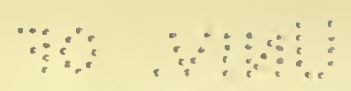

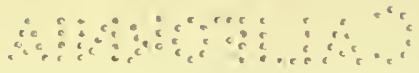




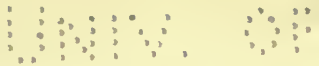

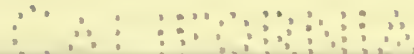

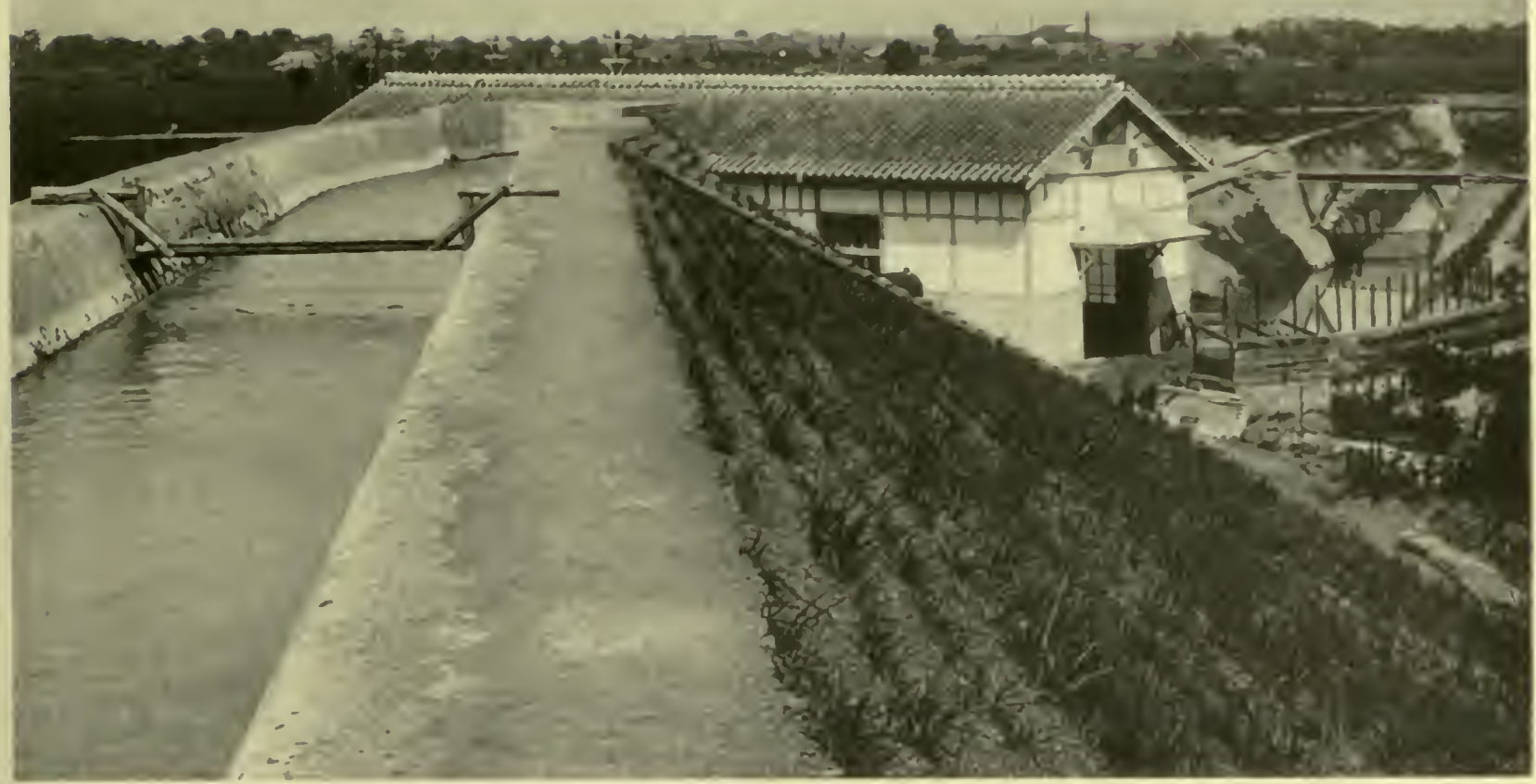

Water Course. 
范

(4) 


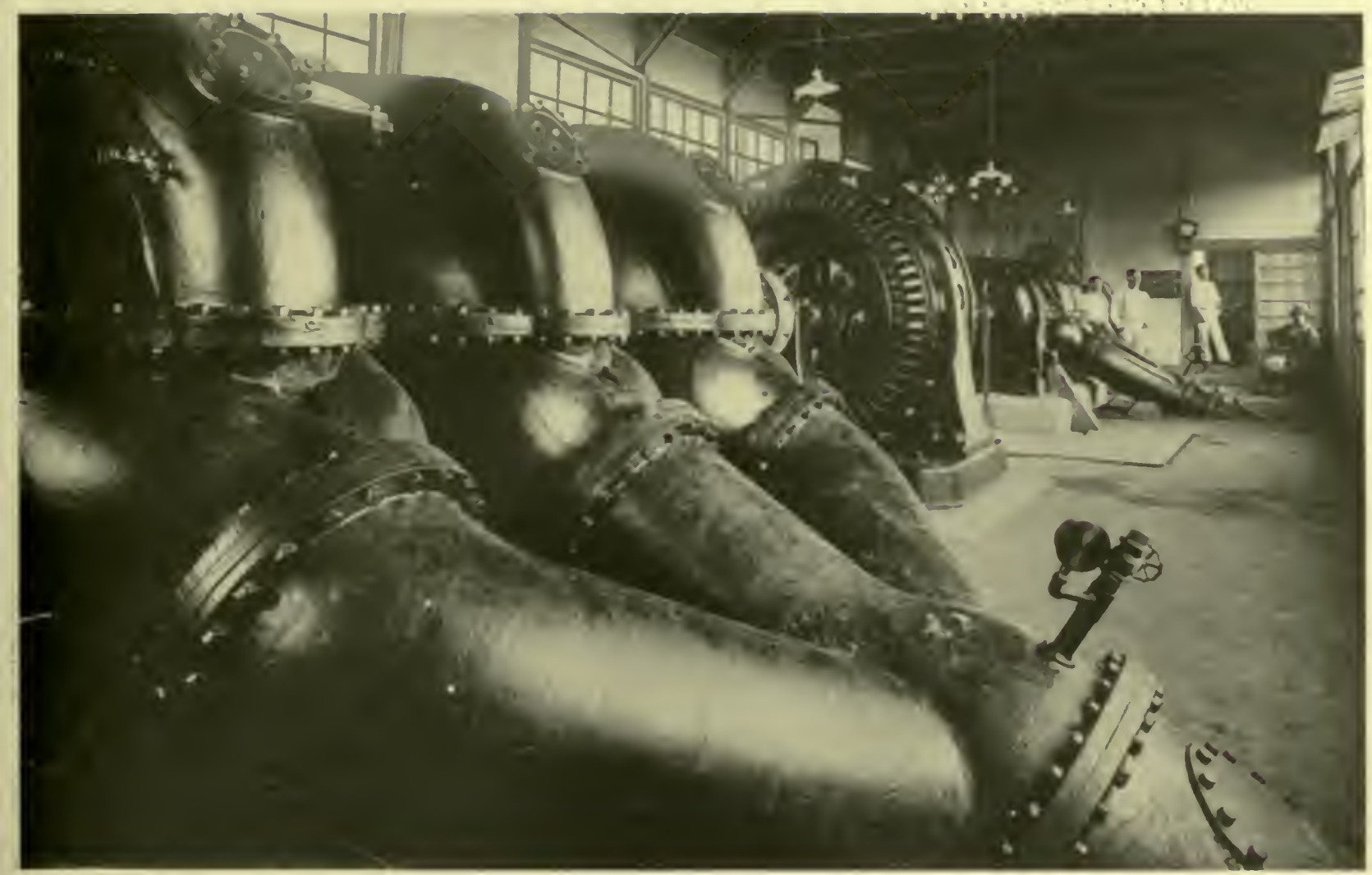

Engine of Drainage. 


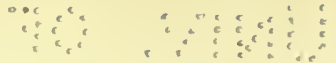

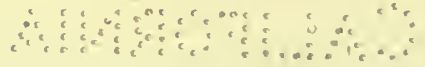




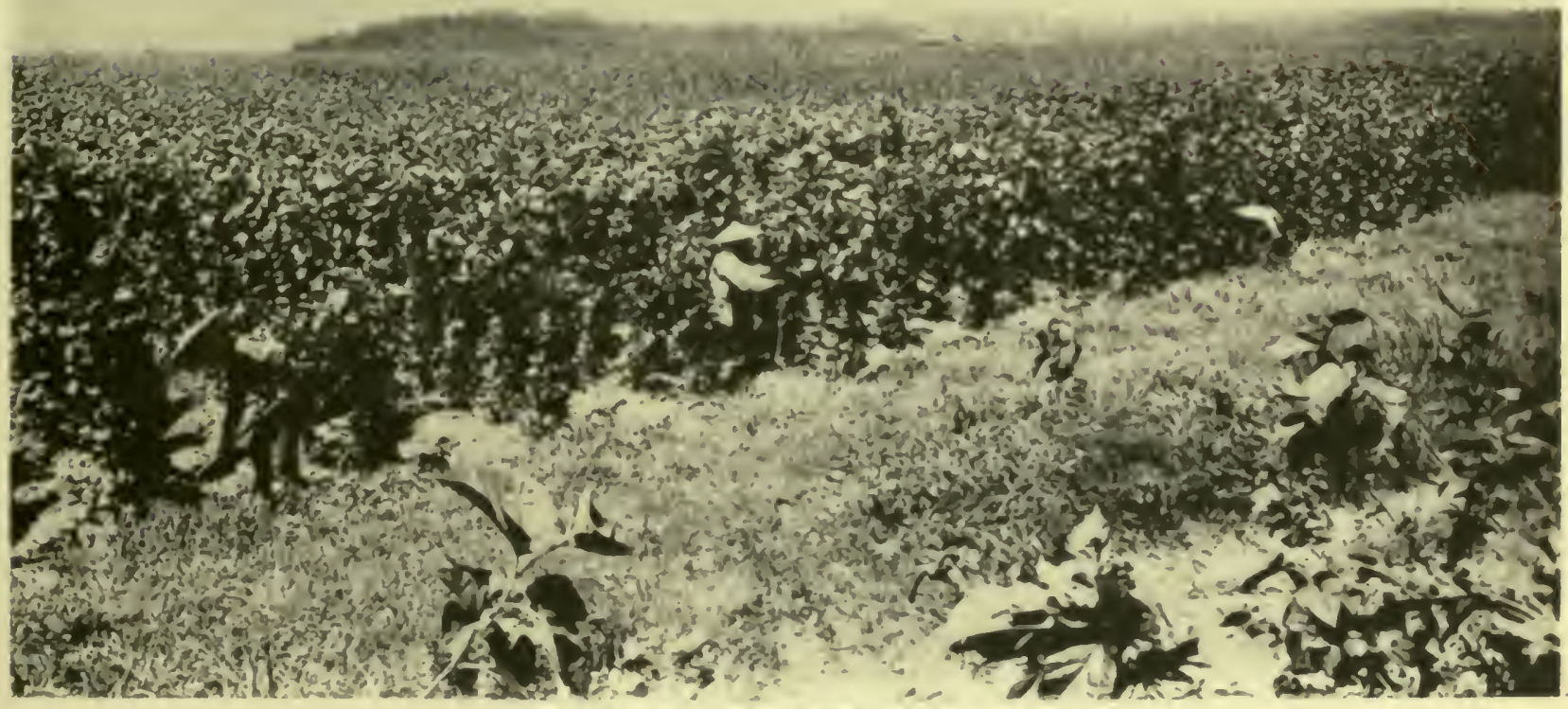

The Bush Plantation of Mulberry trees. 


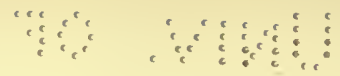

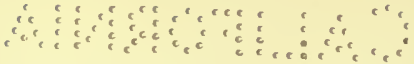




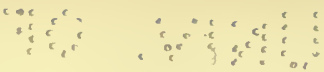

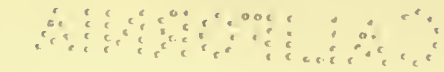

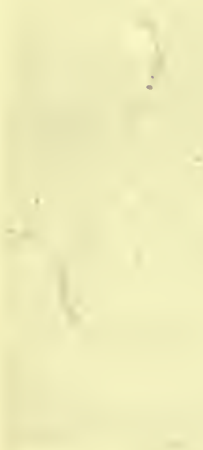




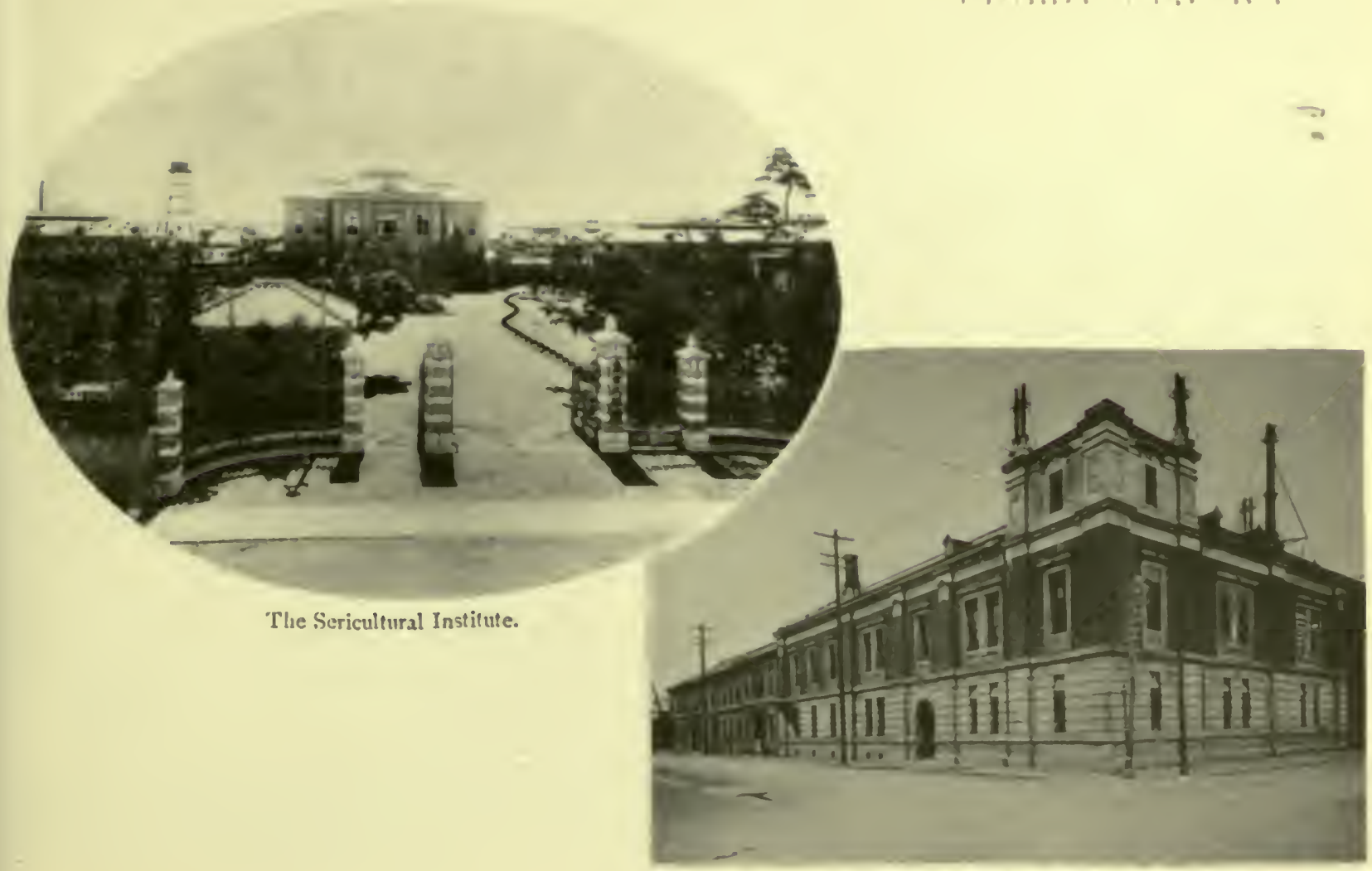

Silk Conditioning House. 
“旅

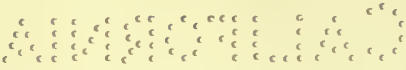




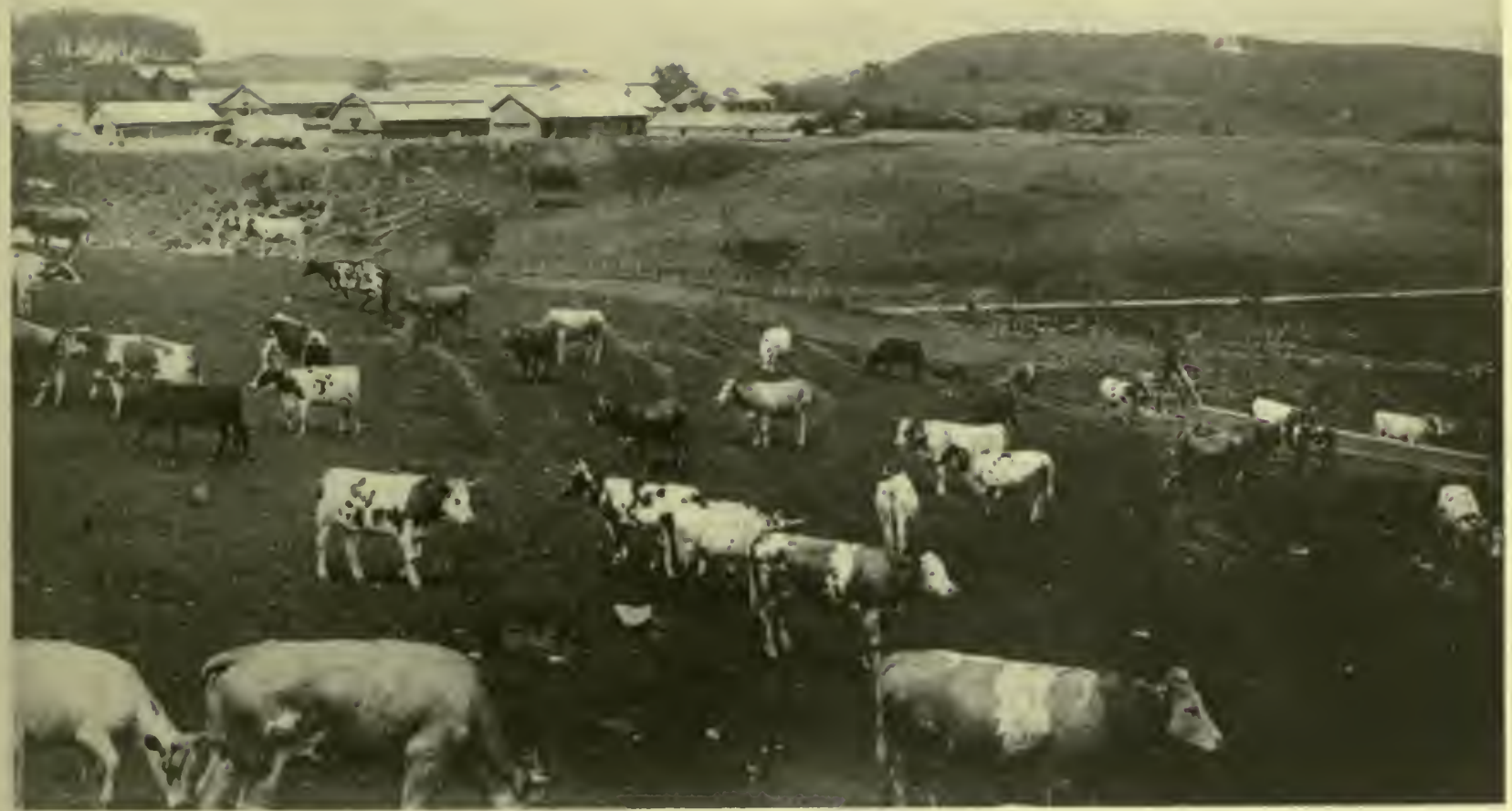

The Government Stock Farm, Nanatsukahara. 


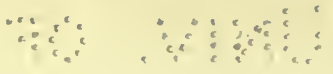

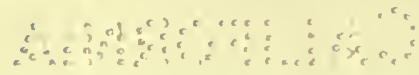




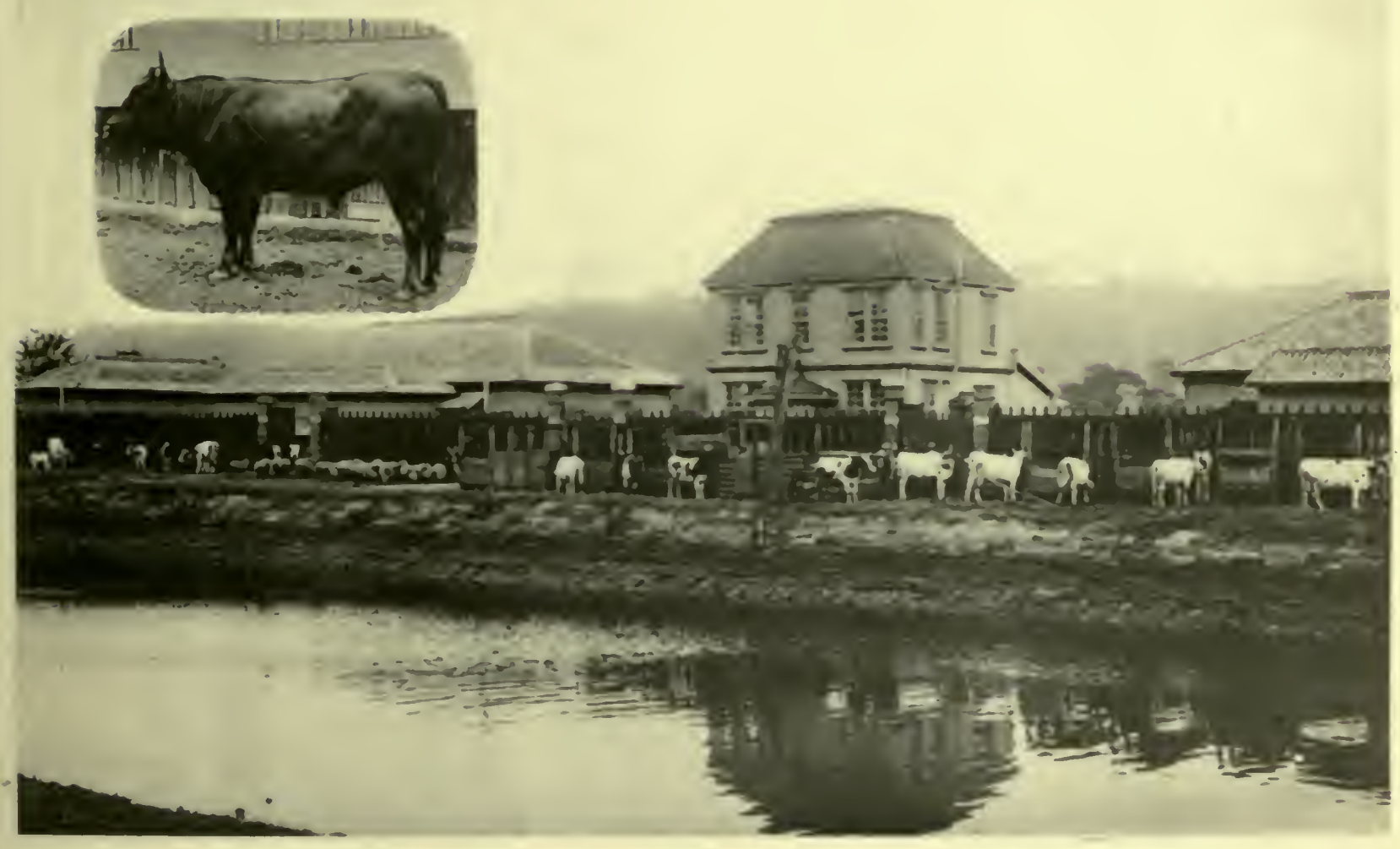

The Animal Quarantine Station (Yokohama) and Jinseki Bull. 
"6

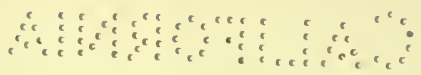




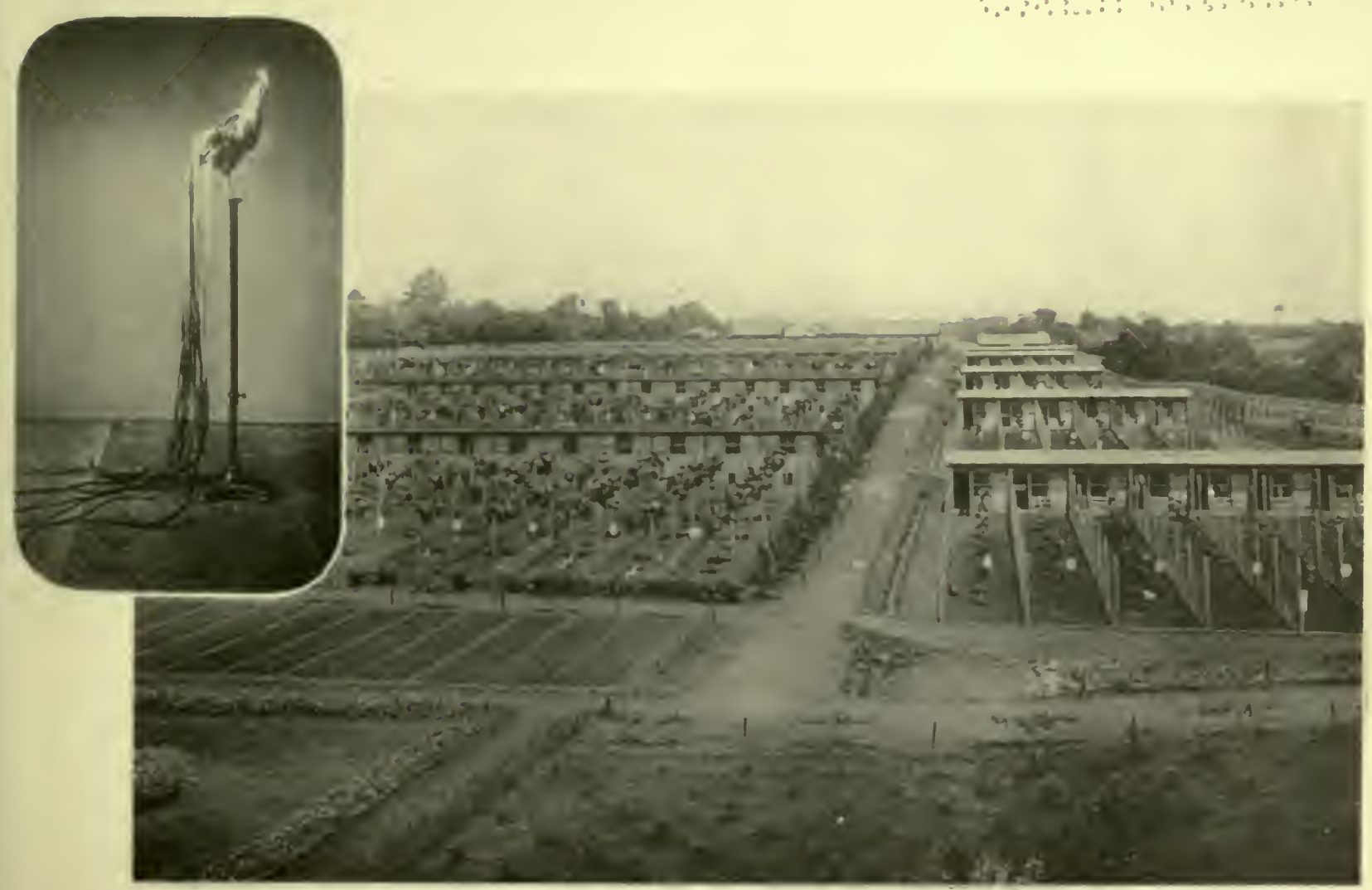

Shibuya Isive-stock Breeding Farm, and Iong Tail Fowl. 
$\because \quad$\begin{tabular}{l}
$\ddots$ \\
\hdashline
\end{tabular}

$\therefore \begin{gathered}0 \\ \therefore\end{gathered}$ 


\section{CHAPTER I.}

\section{CONDITION OF AGRICULTURE.}

\section{POSITION OF AGRICULTURE.}

Indeed, the Japanese Agriculture has a very remote origin. Historically considered, the Emperors, generation after generation, directed their attention to the encouragement of this noble industry ; consequently, in the carlicst times, it already accomplished a phenomenal development, of which the people werc so prond that they ,used to call their land "Mizuinono Kuni" (literally transiated: the "Land of Luxurious Rice Crops"). Such having the case, it is no wonder that agriculture, in any age of past, formed the basis of the national resources.

Although the width of our Island Empire is limited, the length is very large and reaches as much as 3.000 miles; therefore, her extremities touch two zones, the temperate and the torrid. Moreover, the soil being very fertile and climatical changes moderate, there are found numerous varieties of plants growing luxuriantly and the crops are, in the greater portion of the land, raised twice a year. In this respect. Japın may well be called a country most con. genial with farming. Thus, in spite of the linitedness of the area of her arable land, it brings forth so enormous an amount of produce, that caters to the people not unly with abundant food-stuff, but also with abundant manufacturing material of industry. Consequently, the 


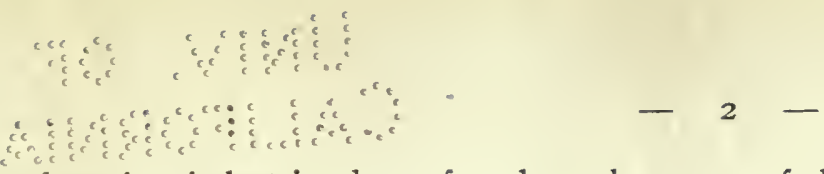

manufacturing industries have found much means of development and this proved to be sitch a contribution for the development of national economy. Agricultural callings are not important in connection with economy only, but are important in social, for, when considered from a hygienic viewpoint, they present another significant aspect. It will be observed that, compared. with those who are engaged in commerce or manufacturing industry, the farmers, as they are in any other country, enjoy better health and have sounder constitution; and their death-rate is low, while the birth-rate is high. It is, therefore, quite natural that they furnish to the Army and Navy more recruits than other classes of people. Next, observing from an ethical point of view, their simplicity, frugality and diligence considerably bear sway over public morals and, consequently, contribute much good to the welfare of nation. Such being the case, it is hardly necessary to say that agriculture should be held in high esteem for sake of the existence of our country.

\section{FARMERS AND THEIR CONDITION.}

Number of Farming Households. - The number of the farming households was 5,510,000 at the end of 1912, that is, about 60 per cent. of all the households in the country. Of the farming household, about 32 per cent. has other occupations, besides farming. The total number of farmers cannot be exactly ascertained, as a proper investigation has not been made; but judging from the average number of persons per household, it is, at least, no less than $30,000,000$.

The Movement of Agricultural Population.-In recent years, there has been a growing 
tendency that the tillers of land give up their callings for other walks of life, owing to the development of commerce and industry and, also, cmigration and colonization. Although the Agricultural population is prevented from falling-off by its natiral increase, the statistics present an indisputable fact that those farmers, whose occupation is agriculture only, are decreasing in number, while those farmers, who follow it together with other callings, are increasing, and that the ratio of farming households against the total number of households in the country is diminishing gradually. However, when regarded from the viewpoint of labour demand and supply, there are, in the country, many places, where the want of the year-or day-labour is very pronounced at times. Notwithstanding, the point is that such places, as suffer from an utter scarcity of tenant farmers, are rare, save a few exceptions.

Classes of Farmers. - The farmers are generally classified among three categories, the landowner, peasant proprietor and the tenant farmer. The first-named farmer is one who rents his land either totally or partly and lives on the rent; the second named is one, who cultivates his own land and depends chiefly on the harvests raised therefrom for his family's livelihood; and the third-named is one, who rents farms from land-owner and till them himself. According to the statistical reports taken at the end of 1912 , the number of the peasant proprictors amounted to 32 per cent. of the total number of farmers, that of the tenant farmer $2 S$ per cent. and that of those, who are at once peasant proprietors and tenant farmers, reached 40 per cent. It is necessary to mention here, however, that some number of small landowners was included in the peasant proprietors. Besides, 
there is a very small number of landowner, who do not put themselves to the actual cultivation of field.

\section{AGRICULTURAI, LAND AND ITS CONDITION.}

Area of Agricultural Land.-Japan, as stated at the outset, is narrow, but long in configuration, and there run through her great and tangled mountain-chains. In consequences, there are few large plains; yet open fields are found almost everywhere along rivers or coasts and are fully exploited as arable land. The area of land under cultivation amounts to about 6,000,000 cho; in other words, 15 per cent. of the total area of the country. Of the acreage, about a half is taken up by paddy field and another equal portion by upland field. Besides these two kinds of farm, there are some fields, whicin are set aside for grazing and other purposes, and which cover an area of about 2,000,000 cho. Again, of the land under cultivation, what is worked by its owner is almost equal, in area, to what is tended by tenant.

Utilisation of Agricultural Land.--Below is given a brief explanation of the utilisation of agricultural land of various descriptions:-

(a) . Paddy Fields. - Paddy fields are, of course, for the raising of rice and are filled with water in the summer season. Rice being the staple food of the Japanese, its cultivation is comparatively profitable, and almust every piece of field, so far as it is provided with ample irrigation facility, is developed as paddy field. Under the circumstances, the paddy field is generally twice or thrice 
higher in price than that of upland fields. It, after the rice crop is harvested and water is drained off, can grow other crops, such as, barley, naked barley, wheat, rape, or weeds for manuring its soil. The paddy field which is harvested twice a year, is called the double crops field. Rut this is not the case with all the paddy fields; some cannot yicld any more than once a year, because of their laving bad drainage, or the cold climate that unables raising the winter crop. Within the last few years, however, as a result of the adjustment of arable land and advancement of the method of cultivation, a great deal of the lands of single crup was clianged: into that of double crops, which shares 40 per cent. of the total area of paddy field.

(6) Upland Fields. - Uplands are those farms, which, being:located in high and dry places, are destitute of means of irrigation and cannot be converted into paddy fields. The utilisation of the upland field is commonly performed by the rotation system and two crops are raised a year; namely, as the summer crops, such harvests as the soja beans, sweet potatos, millet, or such raw materials for manufacturing inclustry as tobacco, liemp, sugar-cane, indigo, and vegetables are cultivated, and as the winter crops, the barley, naked barley, wheat, rape, and vegetables. With reference to cultivating vegetables in the farmlands outlying a city, the utilisation of land is so extremely intensive that, at least, three crops are produced a year. As to the plants, which are cultivated in upland field, there are the mulberry, tea, fruit trees, paper muber'y and others, among which the mulberry is, of course, most important, in connection with sericulture.

(c) Plains.-The plain here refers to those portions of land, overgrown with grasses, which 
are located in high land or mountain slope or in secluded place. The employment of a plain aims at the growing of fodder. The grasses growing in woods, foot-paths and banks of paddy fields serve also for the same purpose, and their profits can not be overlooked.

Adjustment of Arable Land.-The allotment of tillable lands is generally narrow, small and irregular in shape; moreover, in allotting them, care has been neglected in providing roads, watercourses, and equipments of irrigation and drainage. In order to remedy the circumstances and facilitate agricultural administration, the Government enacted the Law of Adjustment of Arable Land, in I90J, for granting many privileges, as a measure of encouragement, to the landowners, when they have decided to carry out a joint adjustment of their holdings. Ever since the enactment of the law, the work was started at more than 6,000 places, the total area of which reaches upwards of 347,000 cho. The work is still earnestly undertaken every year.

Reclamation of Land.-In the Law of Adjustment of Arable Land, provisions are made for affording many privileges, as a measure of encouragement, for the reclamation of waste land, lake and marsh, etc. Although the investigation into reclaimable land is not yet completed, it is believ. ed that the area of this sort of land is very extensive.

\section{MANAGEMENT OF AGRICULTURE.}

Outline of Management.--The agriculture of Japan is conducted on a small scale and is intensive. Formally, labour was chiefly limited to the raising of cereals and cattle was bred simply 
or helping the work in field. In recent years, however, the method of farm management accomplished a complete change, as a result of the advancement of agriculture, and to-day livestock breeding, sericulture, horticulture, and handcrafts of simple nature have become to be undertaken as subsidiary works. Moreover, the farm has been so cultivated as to yield two crops a year, whenever this is possible. The purpose is, of course, to facilitate an even distribution of labour and increase production.

Utilisation of Animal Labour. - In consequence of the smallness of its scale, the agriculture of Japan used to rely principally on human labour for opcration and, therefore, very little of animal work was in demand. But owing to the economization of labour, deep ploughing, supply of stable manure, etc., animal labour has come into widespread use and the number of livestock kept has of late years shown some increase. According to an investigation made at the end of 1912, there were in the country $2,200,000$ heads of livestock, of which $1,220,000$ heads were horses and the rest cattle.

Amount of consumption of Fertilizers. - About twenty years ago, the fertilizer meant chietly the human excrement, weed, stable mamures and also. And, also, small amounts of such fertilizers as oil-cake, fish-guano and rice bran. Since then, however, with the progress of agriculture, the demand for the various kinds of fertilizers has remarkably increased and the amount of consumption, in the year 1912, reached $\$ 8,000,000 y(n$ in valuc. If such sorts as the rice bran, soylees, ashes of plants, and others, which can be manulactured without license, are taken into consideration and 
calculated together, the total amount of consumption must be well over 100,000,000 yen in value. When the sum is compared with that ten years ago, it is three times as Jarge. Of these market manures, the bean-cake, which is imported from China and Kwantung Peninsula, is most important and demanded to the sum of about 25,000,000 $y \in n$. Next come the various composition manures, the material of which is imported in large quantities, and super-phosphates of lime. As to the stable manures, made by farmers themselves, and human excrements, the amount is appraised at about I 50,000,000 yen.

Subsidiary Occupations of Farmers.-As already stated, the subsidiary works have now attained such importance as to be indispensable for the management of farming business. Of all the subsidiary callings, sericulture is the most important. Next come such domestic handcrafts as the various kinds of straw works and tea manufacturing, silk reeling, the manufacture of straw braids, chip braids, matting and fancy matting, weaving, paper-making, and manufacture of bamboo, wood, and osier works, and starch. It is generally conceded that even livestock and poultry breedings and horticulture are more suitable as subsidiary callings than as the regular, full-standing ones. As to other occupations of subsidiary nature, it is observed that those, who live about wood-land, devote themselves to forestry in the intervals of farming seasons; those, who live along rivers or the sea, apply themselves to the exploitation of fishery; and those, who live near big cities, obtain jobs as wage-earners. The incomes derived in this manner go a long way in helping their household expenses. 
Co-operative Manaģement.-For our farmers, whose occupations, as already treated, are conducted on a very small scale, it is of utmost importance to afford the facilitics of co-operation for their monetary circulation and saving of fund, so that they may be ab!e to conduct their purchase of materinl and sale of produce in a profitable way and provide jointly any necessary equipment for the benefit of their work. In order to meet the need of this necessary co-operation, the Government promulgated the Co-operative Societies Law in 1900 and endeavoured to make use of it, always. Consequently, the number of co-operative societies has been increasing year after year and their benefit has become very prevalent. According to provisions of the law, the organizations can be divided among four classes; the Credit Society, the I'urchase Society, the Sales Society and the Productive Society; and each class of them is authorised to do the businesses of others, together with its own. On December 31, I913, there were altogether 10,455 societics, of which 8,530 were credit socicties and those which combined in their own the busincss of a credit society, 6,7 Io were purchase societies and those, who combined in their own the business of a purchase society, 4,537 were sales societies and those, which combined in tneir own the business of a sale society and I,46I were productive societies and those, which combined in their own the business of a productive society. The members of these societics aggregated I, I60,000, of whom farmers were numbered by 950,000 , or So per cent. When calculated in percentage. This shows an unmistakable fact that the organization is a great boon for farming community. In I909, the Co-operative Societies Law was revised, which fact resulted in the establishment of the confederate association and central 
association of co-operative societies. In the year I9I3, the former associations were numbered by fifty-two in all and there is every reason to believe that they will prove a great benefit for the development of the great system of co-operation. The later association has its head office in Tokyo and branches at different localities. 'Its object is to disseminate the knowledge regarding co-operative society among people, effect close, mutual connections among the societies already established, and give them guidance and encouragement. Besides the above mentioned, there are still several more organs and institutions for ce-operative management, such as the guilds of various kinds, arable land adjustment associations, agricultural societies, and judicial persons and partnerships recognized by the Civil Code, which are too numerous to enumerate here.

\section{CHAPTER II.}

\section{AGRICULTURAL PRODUCTS.}

\section{THE TOTAL AMOUNT OF AGRICULTURAI, PRODUCTS.}

The total amount of agricultural products, as given out in the official statistics, is roughly 
estimated at $1,720,000,000$ yen in value, the calculation being based on the average figures for the three years preceding the year 1912. But the amount is believed to increase to I,800,000,000 $\mathrm{jen}$, when all other miscellaneous products and by-products are calculated. The following table will give the staple products and this amounts of produce:-

Amount of Agricultural Products.

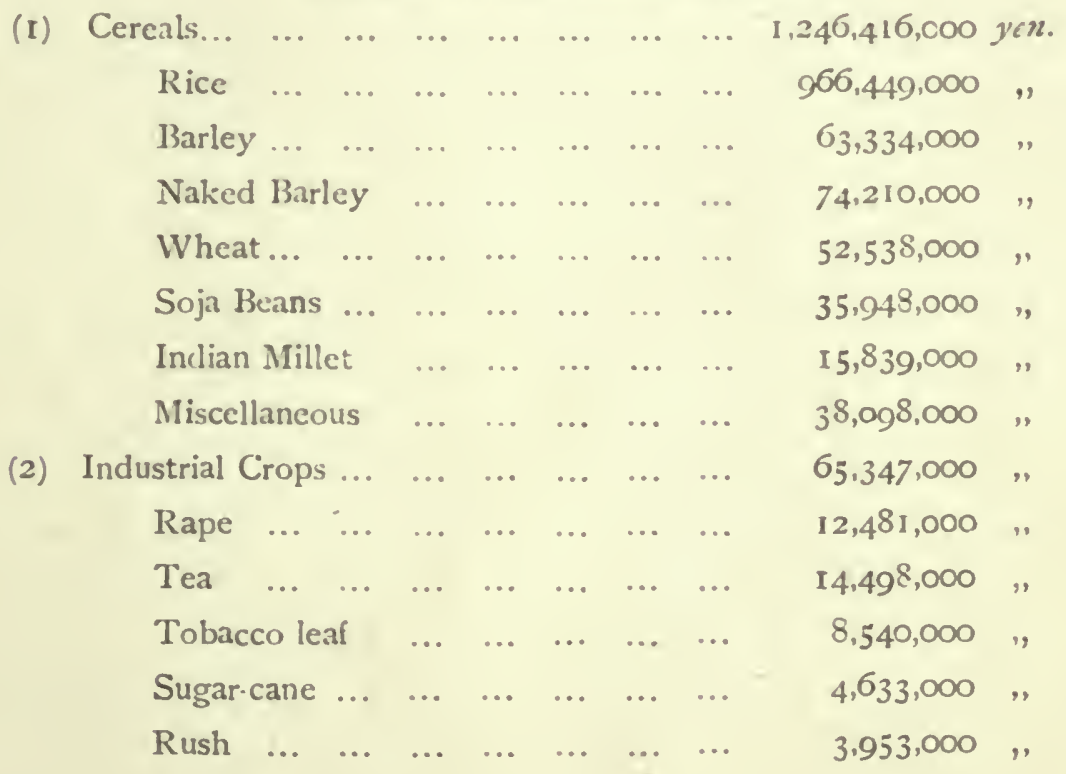


Miscellaneous $\quad \ldots \quad \ldots \quad \ldots \quad \ldots \quad \ldots \quad \quad 2 \mathrm{I}, 242,000$ yen.

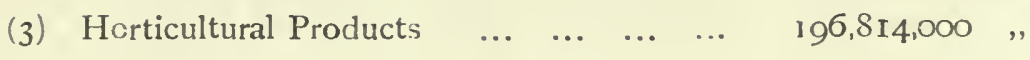

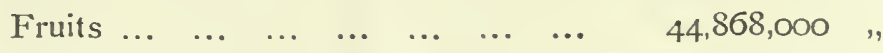

Vegetables, Flowers \&c. ... ... ... $151,946,000 \quad$,

(4) Livestock and Poultry $\quad \ldots \quad \ldots \quad \ldots \quad \ldots \quad 4 \quad 42,273,000$,

Livestock and its products $\ldots . . . \quad 22,46 \mathrm{I}, 000 \quad$,

Poultry and its products $\ldots . . . \quad \ldots \quad$ I9,812,000 ,

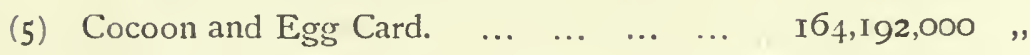

Cocoon... $\quad \ldots \quad \ldots \quad \ldots \quad \ldots \quad \ldots \quad \ldots \quad \ldots \quad$ I 47,6 I $4,000 \quad$,

$\begin{array}{lllllllll}\text { Egg Card } & \ldots & \ldots & \ldots & \ldots & \ldots & \ldots & 16,577,000 \quad,\end{array}$

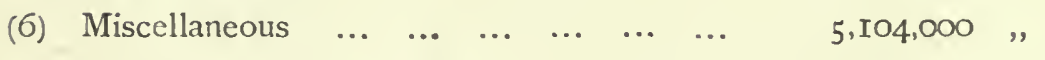

$\begin{array}{llllllllll}\text { Totol } & \ldots & \ldots & \ldots & \ldots & \ldots & \ldots & \ldots & \mathrm{I}, 720, \mathrm{I} 46,000 & ,\end{array}$

\section{AGRICULTURAL CROPS.}

The agricultural produce is yearly increasing, as shown in the tables below :-

(1) Acreages of the Principal Crops.

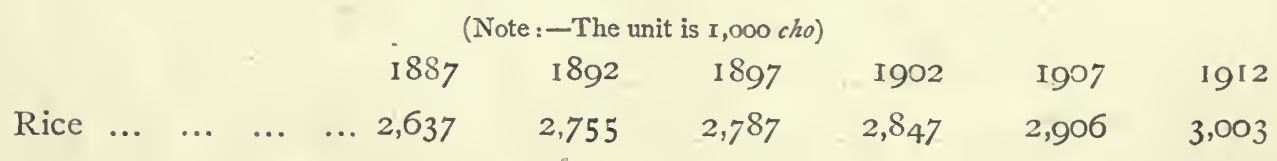


- $13-$

\begin{tabular}{|c|c|c|c|c|c|c|c|c|}
\hline Barley $\quad \ldots$ & $\cdots$ & $\cdots$ & 625 & 635 & 633 & 645 & $65 s$ & 598 \\
\hline Naked Barley & $\cdots$ & $\cdots$ & 575 & 649 & 675 & 682 & 694 & 6So \\
\hline Wheat $\quad .$. & $\ldots$ & $\ldots$ & 390 & 434 & 458 & ${ }_{4} \mathrm{~S}_{4}$ & $4+4$ & $49^{5}$ \\
\hline Indian Millet & $\cdots$ & $\because$ & 243 & 239 & 250 & 226 & 202 & I So \\
\hline Sorghum ... & $\cdots$ & $\cdots$ & 27 & 27 & 27 & 34 & 30 & 33 \\
\hline Barnyard Millet & t... & $\cdots$ & 87 & 90 & 74 & 70 & 62 & 56 \\
\hline Soja Bean ... & $\cdots$ & $\ldots$ & 466 & 443 & 435 & 466 & 471 & 475 \\
\hline Small Red Bea & & $\cdots$ & - & - & 139 & 129 & 135 & 136 \\
\hline Backwheat... & $\cdots$ & $\cdots$ & $15^{8}$ & 161 & 174 & 165 & 166 & 146 \\
\hline Swcet Potato & $\cdots$ & $\cdots$ & 221 & 243 & 259 & 276 & $28 S$ & 299 \\
\hline Potato & $\cdots$ & $\cdots$ & 16 & 21 & $2 S$ & 42 & 60 & 70 \\
\hline Rape ... ... & $\cdots$ & $\cdots$ & 167 & 171 & I 54 & 157 & 143 & 1,36 \\
\hline Tea $\ldots$ & $\cdots$ & $\ldots$ & - & 60 & 58 & 49 & 50 & 48 \\
\hline Mulberry ... & $\cdots$ & $\cdots$ & - & 231 & 298 & 316 & 390 & 453 \\
\hline Cotton & $\cdots$ & $\cdots$ & 98 & $7 \mathrm{I}$ & 44 & 20 & 7 & \\
\hline Hemp... & $\cdots$ & $\cdots$ & 14 & I 8 & 22 & 16 & 13 & \\
\hline Indigo & $\cdots$ & $\cdots$ & 50 & 44 & 50 & 37 & I4 & \\
\hline Tobacco I,eaf & $\cdots$ & $\ldots$ & 21 & 29 & $3 I$ & 23 & 31 & \\
\hline
\end{tabular}


(2) Yields of Principal Crops.

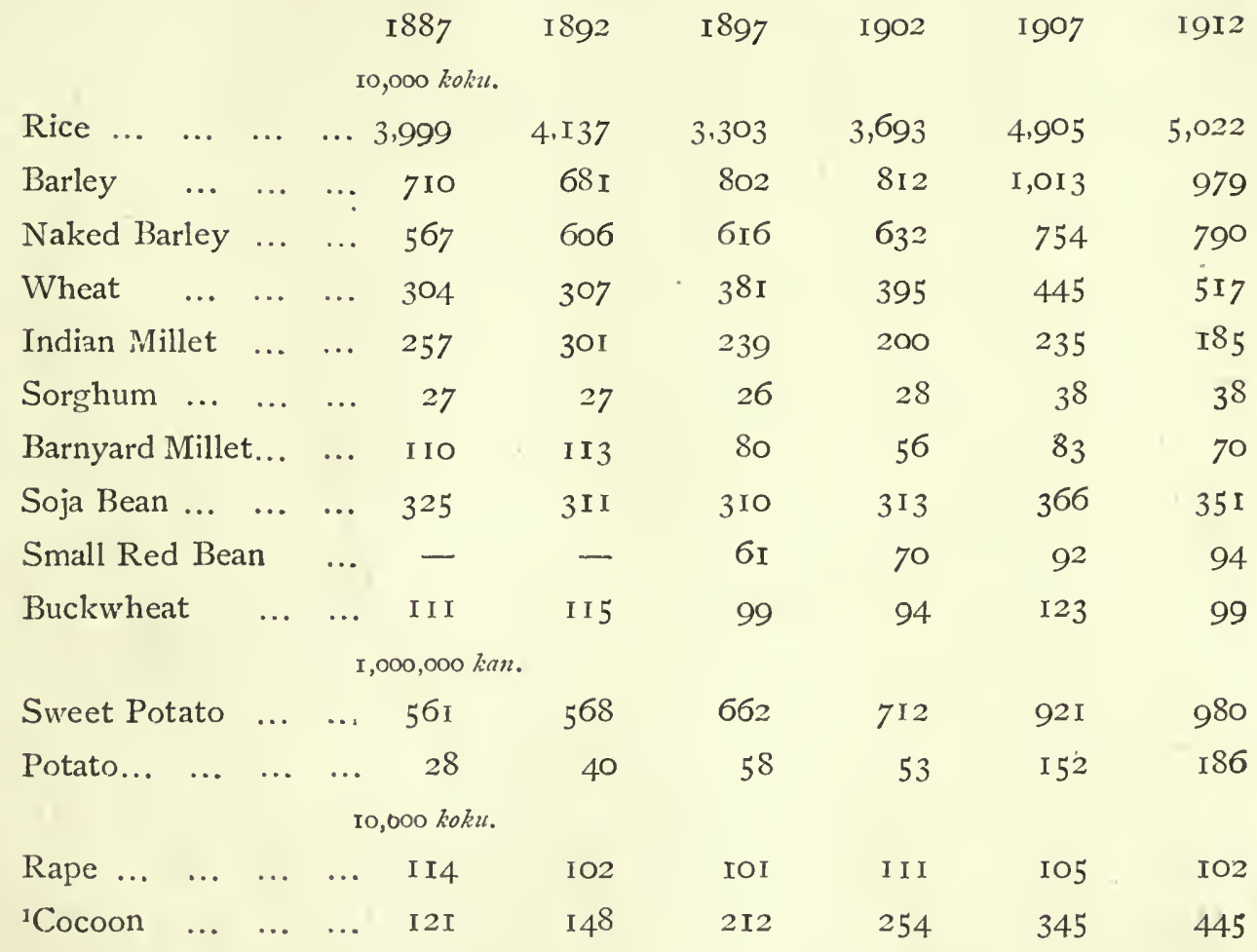


$10,000 \mathrm{kin}$.

$\begin{array}{lrrrrrrrrr}{ }^{2} \text { Tea } \ldots & \ldots & \ldots & \ldots & 701 & 721 & 847 & 678 & 731 & 877 \\ \text { Cotton } & \ldots & \ldots & \ldots & 2,238 & 1,258 & 730 & 332 & 142 & 87 \\ \text { Hemp } \ldots & \ldots & \ldots & \ldots & 239 & 274 & 356 & 268 & 250 & 237 \\ \text { Indigo } & \ldots & \ldots & \ldots & 1,542 & 1,544 & 1,941 & 1,249 & 633 & 281 \\ \text { Tobaccn } & \ldots & \ldots & \ldots & 598 & 764 & 887 & 834 & 1,214 & 1,162\end{array}$

1. The mulberry are shown with the cocoons.

2. It is likely that some amount of tea leaves was not properly calculatec.

Thus, by comparing the yields of the most important of the above crops of 1912, with their predecessors of 1887 , it may be noted that the rice accomplished an increase of 26 per cent., the barley $3^{8}$ per cent., the naked barley 39 per cent. and the wheat yo per cent. As to cotton and indigo, it is observed that their outputs, contrary to those of other crops, fell off to a large extent, as seen in the above tablc. The reason is the effects of imports; and though this is regretable, we note, on the other hand, that such crops as mulberry, fruit trees, vegetable, peanuts, peppermint, lily bulb and towel gourd, have remarkably increased.

\section{SILK INDUSTRY.}

In recent years, among all the industries, the silk industry has accomplished a most remarkable development. Raw silk, undoubtedly, holds the most important position in our export trade and 
its amount of exportation is yearly advancing, that of I9I3 reaching the figure of $200,000,000$ y'en, of which 70 per cent. was sent to America. Compared with the sum ten years ago, its increase is by twice and a half and that twenty years ago, six times as much. To-day, Japan and China are the two largest silk-producing countries and in the greatness of export, Japan heads all other nations of the world. The silk industry is so widespread in Japan that there is no place where it is not followed; but its largest centres are Nagano, Gumma, Saitama, Aichi and Fukushima Prefectures. Of late, the method of raising silkworm achieved a marked progress and cocoons are harvested two or three times a year; at times more than thrice. As sericulture can be conducted on a small scale, it is a suitable and profitable subsidiary occupation and is undertaken by 30 per cent. of the farming people.

In former times, the reeling of cocoons was performed manually by the wives and daughters of farmers; but to-day, mechanical reeling has come into its own; and 70 per cent. of the total production of raw silk is turned out by machinery. The rest is done as a domestic occupation of farm women.

Below is given a table for showing the progress of the silk industry.

\begin{tabular}{|c|c|c|c|c|c|}
\hline & & $\begin{array}{l}\text { I897 } \\
\quad \text { koku. }\end{array}$ & 1902 & 1907 & 1912 \\
\hline Output of Cocoons & $\ldots$ & $\begin{array}{r}\ldots 2, \mathrm{I} 20,000 \\
\text { keln. }\end{array}$ & $2,549,000$ & $3,457,000$ & $4,452,000$ \\
\hline Output of Raw Silk & ... & $\ldots \mathrm{I}, 537,000$ & $2,55^{\mathrm{S}, 000}$ & $3,228,000$ & $4,728,000$ \\
\hline
\end{tabular}




\section{ANIMAL INDUSTRY AND POULTRY.}

The livestock farming, owing to the difference of the circumstances in Japan from those of the European and American nation;, makes but a very slow progress. At present, the number of domestic animals is no more than 1,400,000 heads of cattle, 1,600,000 heads of horses, and 300,000 heads of swine. Sheep and goats are very small in number and not worthy of reference. But great importance is attacked to this industry by the people and the Government is also encouraging with every possible measure its development, so that in the future, there, it is expected, will be something remarkable about this branch of agriculture. Even, to-day, though the number of the animals has not shown any decided increase. breed has been greatly improved, owing to the introduction of better species from abroad. Poultry-breeding is carried on chiefly as the subsidiary calling of farmer. According to the statistics of 1912, the total number of the houscholds, which are engaged in chicken-raising, was $2,900,000$; that of cocks and hens $12,000,000$, that of young chickens $7,500,000$, and the output of eggs $800,000,000$, which, when appraised in money, reached $16,000,000 y c n$ in value. There is every appcarance that the poultry business will further continue to grow.

\section{TRADE OF AGRICULTURAL PRODUCTS.}

The average annual amount of agricultural exports, for the three years preceding 1913 , amounted to $234,390,000 \mathrm{y} / \mathrm{n}$, while that of the imports $343,560,000 \mathrm{yen}$. When the matters are considered 
under the light of the whole foreign trade, the exports become as much as 44 per cent. of the entire export trade and imports 55 per cent. of the import trade. When compared with those fifteen years ago, the agricultural produce has increased 3.3 times in export and 2.7 times in import. Below are given the figures for the average annual exports and imports of the principal agricultural products for the three years prior to 1913 :-

Exports.

\begin{tabular}{|c|c|c|c|c|}
\hline Articles & & & & Value \\
\hline Raw Silk ... & $\ldots$ & $\ldots$ & $\ldots$ & 166,963 \\
\hline Tea ... ... & $\ldots$ & ... & $\ldots$ & I 2,639 \\
\hline Sugar ... ... & $\ldots$ & $\ldots$. & $\ldots$ & $10,3^{8} 4$ \\
\hline Straw Braids & $\ldots$ & $\ldots$ & ... & 4,924 \\
\hline Vegetables \& & Fruit & s... & ... & 4,493 \\
\hline Rice $\quad \ldots \quad \ldots$ & $\ldots$ & $\ldots$ & .. & 4,227 \\
\hline Fancy Matting & $\ldots$ & $\ldots$ & $\ldots$ & $3,85 \mathrm{I}$ \\
\hline
\end{tabular}

Imports.

\begin{tabular}{|c|c|c|c|c|c|}
\hline & & & & & \\
\hline Cotton & & & & - & \\
\hline Bean Cake. & $\ldots$ & & & & \\
\hline Rice & & & $\ldots$ & & 32,128 \\
\hline Wool ... & $\cdots$ & & $\cdots$ & .. & $\mathrm{I} 4,53 \mathrm{I}$ \\
\hline r... & $\cdots$ & & $\ldots$ & & 20,694 \\
\hline Bean . & $\cdots$ & & $\cdots$ & & $8,57 \mathrm{I}$ \\
\hline & & & $\ldots$ & & $6,82 c$ \\
\hline
\end{tabular}

Of the articles,mentioned above, the importation of cotton has remarkably increased in recent years. This shows the development of home industry; and it is observed that the cotton yarn and cloth, which are manufactured from the imported raw cotton, are now exported to half the amount of raw cotton imp.rt. Bean-cakes are imported, as an imported article of manure. Owing to the 
increase of population, rice and wheat show a tendency of growth; but, when compared with the total amount of crops of the country, the imports are no more than 4 or 5 per cent. Among the agricultural exports to the United Statcs, raw silk stands first, the amount having excecded 120,000, 000 yen in 1913, next teas, the amount reaches about 10,000,000 yen. Besides, fancy matting, straw braid, rice, beans, peanut, menthol crystals, peppermint oil, lily bulbs, canned vegetable, orange and dried cayenne pepper are worthy of attention.

\section{CHAP'TER III.}

\section{AGRICULTURAL ADMINISTRATION.}

\section{ORGANS OF AGRICULTURAL ADMINISTRATION.}

Central Organs of Agricultural Administration.-The highest organ of agricultural adninistration is the Department of Agriculture and Commerce, over which the Minister of Agriculture and Commerce presides. In it, is the Bureau of Agricultural Affairs, which stands on the same footing with the Commercial and Industrial Bureau, Forestry Bureau, Fisheries-Bureau and Mining Bureatr. 
The bureau embraces the five sections of agricultural administration, arable land adjustment, agricultural products, sericulture, and animal industry, each of which respectively deals with its own affairs, relating to agricultural administration. There are still other organs under the direct control of the Department of Agriculture and commerce, such as the agricultural experimental station, silk conditioning house, sericultural institute, government stock farm, cattle breeding station, Anti Rinder pest serum institute, and plant quarantine office. As for the horse administration, there is the Horse Administration Bureau, which is superintended by the Minister of Military Department.

Local Organs of Agricultural Administration.--The local agricultural administration is superintended by the Governor of Prefectures, and is directly entrusted with the Section of Agricultural Affairs, or Section of Industry. Besides these two, there are agricultural experimental stations, stock breeding farm, rice inspecting offices, sericultural inspecting officcs and manufacturing offices of reproductive silk-worm eggs. The business of each one of them is, of course, the encouragement of their respective branches of agriculture. With reference to the administration of "gun " (county), several officials are engaged by the "guncho" (governor of the gun) for directing the agricultural affairs of the lowest communes, the township and the village.

\section{ORGANS OF AGRICULTURAL RESEARCH.}

The Imperial Agricultural Experimental Station. - This institute is under the direct control of the Agricultural and Commercial Department, and holds the highest position among all the 
organs of agricultural research. The work of the station is classified under nine divisions, the agri culture, agricultural chemistry, entomology, pathology, tobacco cultivation, horticulture, stock breeding, soil investigation and tea manufacturing, each of which is directed by a learned specialist. It is located at a suburb of Tokyo. It maintains three braich stations, respectively in the norticru, middie and southern parts of the country, and some other special horticultural farms.

Local Agricultural Experimental Stations. - The object of the local experimental station of agriculture is to conduct agricultural researches, accordi:g to the particular circumstances of each county of the country, and at the same time to put into practice the results of its researches and promote the scientific knowledge of the farming people. At present, there are thirty nine of these stations throughout the country. Although they are maintained and managed by the prefecture, the "gun", or its agricultural association. may establish one, if they so choose. The Government grants subsidies, in order to encourage the establishment of these useful institutes.

Sericultural Institute. - As for the organs of sericulture, there are the Sericultural Institute and its six branches. They are engaged in performing an abstruse research about improving sericulture and production of silkworm $\mathrm{egg}$ for reproduction. The silk conditioning house is engaged in the investigation of raw silk, in addition to its principal business of inspecting. These two organs are under the direct control of the Department of Agriculture and Conımerce. 
Government Stock Farm and Cattle Breeding Station.-As for raising livestock, there are two Government stock farms and one branch farm, one cattle breeding station, and one institute for the infections.diseases of animals. These are all under the direct control of the Department of Agriculture and Commerce. Besides them, there are seven local stock breeding farms.

Stallion Stud and Stallion Depot.-The affairs relating to breeding horses and improving their stock are entrusted with the Bureau of Horse Administration of the Military Department, and for this purpose, three stallion studs, one stallion rearing station and fifteen other farms are maintained, where, besides their own business, an extensive study of the horse is conducted.

Miscellaneous.-Besides the above-named ones, agricultural research is carried on in experimental farms and laboratories of the Agricultural Colleges and schools.

\section{EDUCATIONAL ORGANS OF AGRICULTURE.}

Higher Organs.-Educational organs of agriculture are mostly under the control of the Department of Education. The highest organs are the Imperial Universities, whose two agricultural colleges are found in Tokyo and Supporo, Hokkaido. Next to the university, come the practical courses of the above named colleges, higher agricultural and forestry schools in Morioka and Kagoshima, higher sericulture and filatural schools in Tokyo and Ueda, Nagano-Ken, Kyoto Higher Sericultural School, the Institute for the Training of Teachers of Agriculture, which is attached to the Tokyo Agricultural College, the private Tokyo Agricultural College and Chiba Horticultural School. 
Common Organs.-As for the common educational organs, there are both middle and low class agricultural schools, agriculture and forestry schools, school of animal husbandry horticultural schools and sericultural schools established by prefectures or public bodies each of which aims at training the middle class farmers.

These are in the country eighty-one middle class schools and one hundred sixty low class schools. Moreover, there are agricultural supplementary schools, which are numbered by 5,06I. The object of these schools is to give supplementary education and, also, the primary education regarding agriculture to those farm lads, who lsave received only the compulsory education. They are mostly maintained by village and town.

Miscellaneous.-Besides the above-mentioned, there are fifteen local Agricultural institutes, which are directed by the Agricultural and Commercial Department. Further, lectures are given to farmers by agricultural societies and agricultural experimental stations, the purpose being to impart them the courses, which are of great value to their respective districts.

\section{PROVISIONS RELATING TO AGRICULTURAL ENCOURAGEMENT.}

The organs of the Government has adopted for encouraging agriculture are mainly as follow :-

A. Agricultural Societies.-An agricultural societies a private judicial person, organised under the Agricultural Societies Law with a view to achieving the progress and development 
of agricultural occupations. It can be divided among four kinds, viz. the Imperial Agricultural Society, Prefectural Agricultural Societies, County and City Agricultural Societies, and Town and Village Agricultural Societies. All of these are established and maintained like one organism. As it can be surmised, there is one Imperial Agricultural Society, fourty-six Prefectural Agricultural Societies, six hundred County and City Agricultural Societies, eleven thousand Town and Village Agricultural Societies; thus, they are found everywhere in Japan, except Okinawa Prefecture. Subsidies are granted them by both the State Treasury and prefectural governments.

B. Co-operative Societies. - The object of the co-operative society is to accomplish the progress of business and economic development of its members. About its details, we already gave a treatment under the head of Co-operative Management, Section 4, Chapter I, so that it is unnecessary to dwell on it here again.

C. Different Kinds of Guilds.--The aim of the stapie products guild is that the producers and dealers in staple products are to unite in rectifying malpractices in their busincss and increase their mutual interests. Such guilds of silk industry number two hundred fifty six, including the confederate associations, whereas those of agricultural products are fifty three in all, including the confederate associations.

Tea guilds aim at achieving improvements in the manufacture of tea, as well as accomplishing the extention of the market. Their number comprises one central chamber, twenty confederate chambers, and two hundred thirteen ordinary guilds. 
Livestock Guilds. - The object of these guilds is to improve the breed of cattle and horses and increase the mutual interest of their members. There are altogether four hundred seventeen guilds, including the confederate associations.

All of the guilds established in accordance with their respective laws.

D. Arable Land Adjustment - The adjustment of arable land is absolutely important for Japan, when viewed from the present condition of the arable land, as already mentioned under the Section 3. Chapter I. Consequently, the Department of Agriculture and Commerce specialiy established a section therefore, with a view to taking various measures for the encouragement of the work, together witls the reclamation of all waste land.

E Inspection of Raw Silk. - The Silk Conditioning House is located in Yokohama and is placed under the jurisdicion of the Department of Agriculture and Commerce. It executes gratis all the requests for raw silk inspection, so as to facilitate the commerce of the article. Also, it is engaged in making investigations about silk industry.

F. Distribution of Silkworm Eggs for Reproduction.- To effect the improvement of raw silk. it is highly necessary to attain an improvement of cocoons and unify their species. Thus, in I9I $I$, the Government establislıcd the Scricultural Institute as an organ for accomplishing the scientific research of the silkworm eggs. Further, the Gisvermment ordered to establish the station for manufacture of silkworm eggs and commitee for selection of cocoon to prefectures and allowed subsidies to them, through which only the best species of silkworm eggs can be supplied to ther aisers of egg-cards. 
G. Crossing of Livestock and Distribution of Hatching-eggs.-At the government stock farms, cattle breeding station of the Agricultural and Commercial Department and all the local stock farms, the people are permitted to bring in their cow, horse and swine for crossing and, also, - the distribution of hatching eggs is carried out, the purpose being the general improvement of the breed of livescock and fowl. Also, at the stallion stud and stallion depot, belonging to the Military Department, the same sort of things is done for the same purpose.

H. : Inspection of Rice.-For the purpose of improving, the quality and methods of drying, preparing and packing of rice, and fix the volume, with a view to improving their value, and to easy their deeling the cereals are subjected to an examination. To-day, there are one " $F u$ " and twenty-five Prefectures, which undertake this as an official work and four prefectures, which do so as a business of agricultural guilds.

I. Official Control of the Commercial Fertilizers. - The Government controls the sale of market fertilizers, according to the Law of Control of Fertilizer. The purpose of the official control is to prevent the unlawful practices of sale and distribute among the prefectural governments the inspectors of fertilizer of the department, who are paid by the State Treasury.

J. Agricultural Monetary Organs. - As the smallest monetary organ, there is the credit society, the business sphere of which is the town, or, the village, or other similar communal district. There are altogether eight thousand five hundred of these credit societies throughout the country. Besides, there are the banks of agriculture and inclustry, whose business territories 
are the entire domains of prefectures, and above and over them is the Hypothec Bank, which does its business all over the Empire. The Government grants them many privileges, for smoothing the circulation of capital for the farming communities.

K. Exhibitions, Shows and Fairs.-The Government, for the encouragement of agriculture and other industries holds exhibitions and moreover, at the same time, aids the competitive exhibitions and fairs which are hold by prefectural government or public organizations.

L. Miscellancous. - With reference to the encouragement of sericulture, there is a fund, set aside for improvement and increase of mulberry farm. About the livestock farming, there are the Regulations of Encouragement of Catele Breeding. Regulations of Inspection of Stud-Bulls, Regulations of Encouragement of Horse Breeding and Regulations of Inspection of stallion; and much money is expended by the State Treasury for these undertakings.

What have been treated above are, each of them, the undertakings of the Government, but there are some special organizations, regarding general agriculture, silk industry, livestock farming, horticulture and others, which are established and maintained by some enthusiastic people. Among them all, the Dai-sihon Agricultural Socicty and Dai-nihon Sericultural Socicty are the most noted ones. The former, which was established about thirty years ago, comprises over Io,ooo members, who are reside all over the country; and it has contributed a great deal to the progress of agriculture. Furthermore, it maintains the Private Tokyo Agricultural College, as a part of its work. The latter, which cnrolls considerably more than 100,000 inembers, has a branch in every 
prefecture and endeavours hard for the guidance and encouragement of silk i: dustries.

\section{PROVISIONS RELATING TO THE PREVENTION OF CALAMITIES.}

The official Provisions relating to calamity prevention in connection with agriculture are mainly as follows :-

A. The Prevention of Flood.-The flood-prevention work is chiefly under charge of the Home Department. The Government maintains offices for superintending embankment and other engineering works, which are carricd on at the places of great importance, and, the embankment work, and, also, for performing investigations about the riparian and other undertakings. Furthermore, the Government has legislated the Riparian Vorks Law so as to have strict control and protection any kind of riparian work. And, also, it has promulgated the Forestry Law and tne Law of Alluvial Prevention and at the same time, established the Forestry and Rain Observatories for the study and prevention of the washouts of sands and floods. Also, it issued the Regulations of Water Corporation by which the guilds are obliged to take charge of embankments, dredging and prevention works of sand washouts.

B. Prevention and Extermination of Plant Disease and Injurious Insects.-The existing Law of Prevention and Extermination of Injurious Insects is applicable to prevention and extermination of the bacteria and other injurious animals, besides insect. In accordance with this law, the Gov- 
ernment may temporarily defray, according to the circumstances, the expenses necessary for the execution of the purpose, with outlays from the State Treasury; besicles, it is provided that the Government shall yearly grant to the prefectural governments appropriations for the simi'ar purposes. The authorities also issued the Game Law, as an indirect method of insect extermination, for the protection of those birds, which feat on the destructive worms and insects.

C. I'revention of Silkworm Diseases. - The measures, which concern with the prevention of silkworm diseases are provided in the Law of Silk Industry. By virtue of this law, the Govern. ment allows subsidies to the provinces for assisting the establishment of a scricultural Inspection office, with a view to the prevention of silkworm diseases. All this effort has accomplished an excellent result and in recent years, the damages of discases have been yearly diminishing.

D. Prevention of Animal Diseases.- This work is strictly undertaken, in connection with the Law of Prevention of Animal Diseases and Law of Prevention of Bovine Tubercle. Further, there are maintained an institute for the investigation and research of animal discases and a rinderpest serum manulactory for the manulacture and distribution of the serum.

E. Inspection of Plants.--In order to prevent the exportation of those agricultural products that are damaged or infected with injurious insect, the Government granted local authorities subsidies and made them carefully inspect and guarantee the exports. l'articularly, in case of the export to America, the plant inspectors of the Central Government had plied themselves direct!y and issued certificates. But, being desirous of exercising more care about the matter, so that all 
the plants, imported into the country, may be inspected, the authorities promulgated in March, I9I4, the Law of Control of Importation and Exportation of Plants and opened inspection offices at the leading foreign trade ports, where the inspectors of the Central Government are at work rigorously.

\section{AGRICULTURAL STATISTICS.}

The Statistics of the Department of Agriculture and Commerce are compiled at the Section of Correspondence in the Secretariat of the Minister of Agriculture and Commerce, the compilation being done with the date furnished by the prefectural governments and offices. These statistical reports, which covers all the matters relative to agricultural products, are issued once a year. As for the probable crops of rice, wheat, and cocoons, the Department makes public the forecast reports.

There are another agricultural statistics, the data of which are collected and furnished by the agricultural societies throughout the country and which are published by the Bureau of Agricultural Affairs. This report will give the reader a most comprehensive survey of the Japanese agriculture. Moreover, the bureau exerts itself for the investigation of industrial and economic matters and gives out at times the results of that investigation. 


\section{CHAPTER IV.}

\section{OUTLINE OF AGRICULTURE IN THE COLONIES.}

\section{AGRICULTURE IN FORMOSA.}

The island of liormosa being situated near the torrid zone, its natural elements are well suitable to agriculture, and its economic basis rests on the industry, too. The area of the land under cultivation there consists of 336,000 cho of paddy fields and 354,000 cho of upland fields. which make up a total of 693,000 cho. The total acreage corresponds to 19 per cent. of the size of the island. The agricultural population numbers $2,000,000$, that is, 60 per cent. of the total population.

Among all the agriculture products, rice is most important, the output of which is $4,500,000$ koku a year, and the value 60,000,000 yen. Next comes the sugar-cane, the value of cane-sugar exceeds 40,000,000 yen a year. Other principal products are sweet potatoes, tea, beans and pcanuts. As to domestic animals, the swine is largest in number, and total $\mathrm{r}, 300,050$ heads. The next largest animal is the buffalo, which is chiefly employed for tilling land and estimated at 300,000 heads. 
Of all the agricultural exports to Japan Proper, the unrefined sugar stands at the head, its value being $28,000,000$ yen a year. Rice follows next and amounts to $10,000,000$ yen in value. Among the exports to foreign countries, tea is the staple one and calculated at $7,000,000$ yen. The unrefined sugar, amounting to $\mathrm{I}, 800,000$ yen in value, is next in order. The brand of tea, exported abroad, is the Oolong and goes to the United States principally.

\section{AGRICULTURE IN CHOSEN}

The total area of arable land in Chosen is estimated at 2,8c0,000 cho, of which $1,000,000$ cho is paddy field and the rest, I,800,000 cho in extent, upland field. When compared with the area of the whole peninsula, it is no more than 12.4 per cent.; so it stands to reason that there is much room for the further increase of it. At the end of 1912 , there were 2,430,000 farming households, the population of which was II,600,000. Of this, 4,383 households, the population of which was $\mathrm{I} 4,505$, were Japanese settlers. The affairs regarding immigration and the development of the resources of Chosen are entrusted with the management of the Oriental Development Company, which was established under the special protection of the Government.

The sorts of agricultural products are almost tle same as those of Japan Proper, and rice comes first. Then, wheat, beans, and Indian millet in order. The acreage of the lands under cultivation and outputs of principal argicultural products of the year I9I2 were as follows :- 
Acreage.

$\begin{array}{lllllll}\text { Rice } & \ldots & \ldots & \ldots & \ldots & \ldots & 980,000 \\ \text { cho }\end{array}$

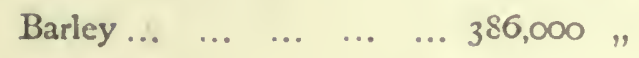

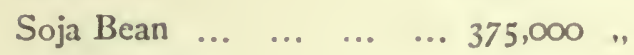

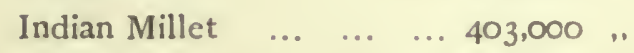

$\begin{array}{lllllll}\text { Wheat } \ldots & \ldots & \ldots & \ldots & \ldots & 169,000 & \text {.. }\end{array}$

Small Red Bean... ... ... 165,000 ..
Output.

$8,969,000$ koku
$4,293,000 \quad$.
$2,452,000 \quad$.
$3,118,000 \quad$ ".
$1,094,000 \quad$ ".
$835,000 \quad$,

The livestock farming of the Chosen is not worthy of mentioning, except, probably, the raising of cattle, the total number of which is about $\mathrm{I}, 000,000$ heads. The agriculture, formerly, had been much backward and inferior in its development, when compared with that of Japan Proper. But the Government-Gencral of Chosen tonk all sorts of measure for its encouragement and established a model farm and its branches all over the country. It is gratifying, however, that the sincere-minded, official effort has been duly recompensed with a remarkable progress of the industry.

The principal agricultural exports both to foreign countries and to Japan proper, in-I9I2, were as follows:-

\section{Exports to Foreign \\ Countries.}

Rice..
Clearances to Japan Proper.

$4,012,000 y e n$
Total.

$6,230,000$ yen 


\begin{tabular}{|c|c|c|c|c|}
\hline Soja Bean & $\ldots$ & 83,000 yen & $4,917,000$ yen & $5,000,000$ yen \\
\hline Cowhides & & $299,000 \quad$, & $732,000 \quad$, & $\mathrm{I}, 032,000$ \\
\hline Cotton & $\ldots$ & $\ldots \ldots \ldots$ & $435,000 \quad$, & 435,000 \\
\hline Ginsing & $\ldots$ & 259,000, & 2,000 & $26 \mathrm{r}, 000$ \\
\hline
\end{tabular}

\section{AGRICULTURE IN KARAFUTO.}

The agriculture of Karafuto was, in former times, not worthy of our serious consideration; but since the island came into the possession of Japan, the Government endeavoured to invite immigrants by offerring many inducements, such as lending houses, seeds and domestic animals. Thus, the number of their households commenced to increase; and at the end of I9I2, there were 2,243 houses of settlers, whose farms altogether amounted to 4,000 cho. Moreover, there is every prospect of the continued increase of the farming population there. According to the investigation of the Colonial Government of Karafuto, there is an area of 130,000 cho, which is capable to be appropriated for cultivation and grazing. As regards the climate, it is observed that the temperature seldom rises above the freezing point during the four months of winter; but in the summer, it sometimes goes up even to $30^{\circ} \mathrm{C}$ and farming can be carried on between May and September. As for agricultural products, barley, naked barley, wheat, oat, rye, rape, buckwheat, peas and potatoes are the principal ones. Also, there were, at the end of I9I2, I,455 heads of cattle and 2,629 heads of Horse. 


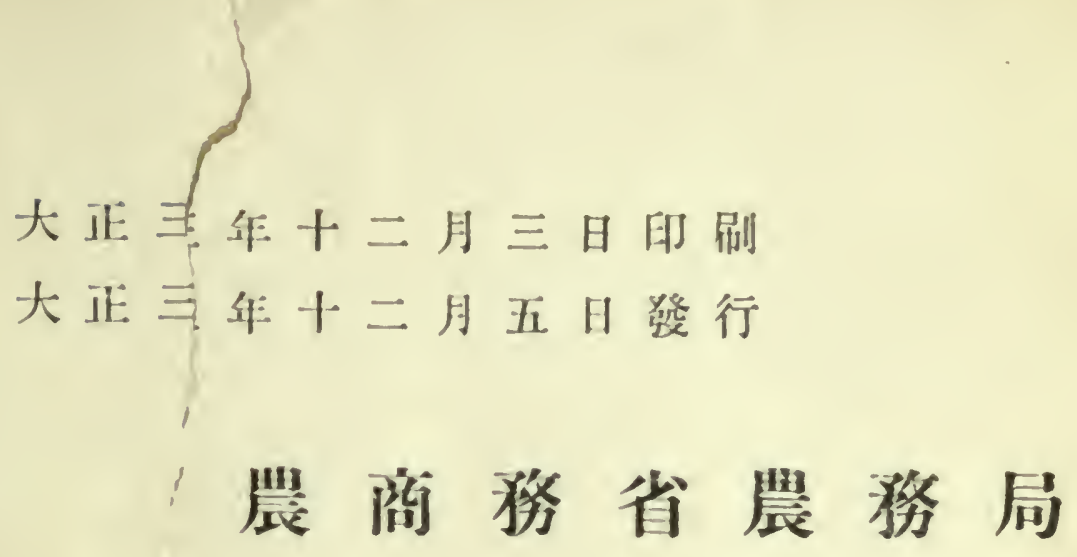

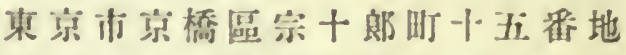
合资會社東京國文社代表者

晸人王监源太郎 來京市京橋區宗十郎町十五番地 红刷所合留来京國文社 $\begin{aligned} & =\text { 五九 } \\ \text { 電話新橋 } & =ニ 0- \\ & =\equiv-九\end{aligned}$ 


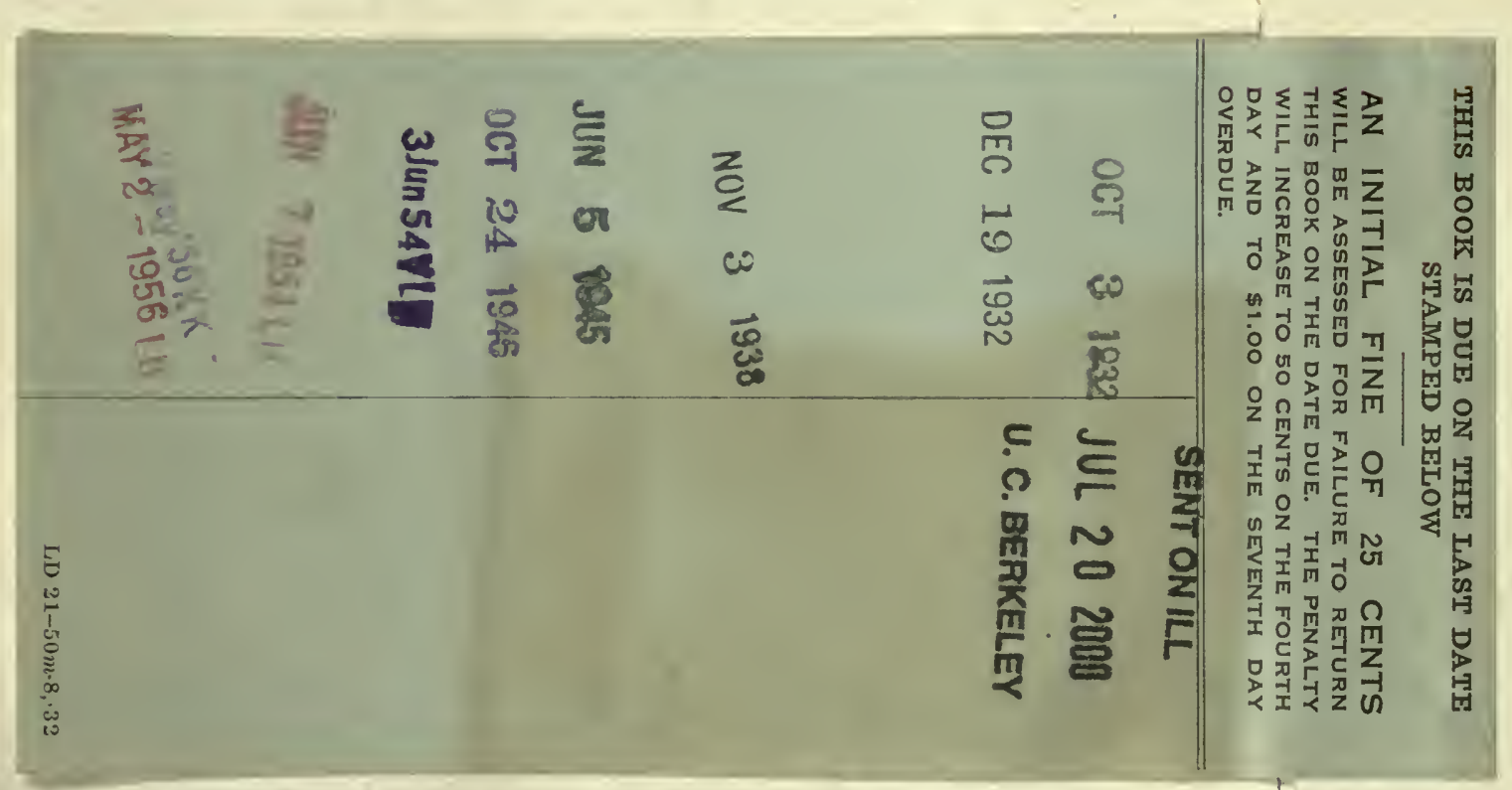




\section{YC 67810}

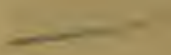


